\title{
Metal bioavailability and distribution in the fish community in a tropical estuary, Sepetiba Bay, Rio de Janeiro, Brazil
}

\author{
Vinicius Tavares Kütter ${ }^{1 *}$ \\ Vanessa Almeida Moreira ${ }^{2}$ \\ Mateus Tavares Kütter ${ }^{3}$ \\ Emmanoel Vieira Silva-Filho ${ }^{2}$ \\ Eduardo Duarte Marques ${ }^{4}$ \\ Jeremie Garnier ${ }^{5,6}$ \\ Edison Dausacker Bidone ${ }^{2}$ \\ ${ }^{1}$ Universidade Federal do Pará \\ Faculdade de Oceanografia \\ Rua Augusto Corrêa ${ }^{\circ} 1$ \\ Belém. PA Brasil \\ ${ }^{2}$ Universidade Federal Fluminense \\ Programa de Pós-Graduação em Geociências \\ (Geoquímica Ambiental) \\ Niterói. RJ Brasil \\ CEP 24020-141 \\ ${ }^{3}$ Universidade Federal do Rio Grande \\ Instituto de Ciências Biológicas \\ Av. Itália km 7 \\ Rio Grande RS Brasi \\ CEP 96201-900 \\ ${ }^{4}$ Serviço Geológico do Brasil \\ SUREG Belo Horizonte \\ Avenida Brasil, 1731. Funcionários \\ Belo Horizonte MG Brasil \\ CEP 30140-002 \\ ${ }^{5}$ Universidade de Brasília \\ Instituto de Geociências \\ Campus Darcy Ribeiro \\ L2, Asa Norte \\ Brasília DF Brasil \\ ${ }^{6}$ Universidade de Brasília \\ Laboratoire Mixte Internationa \\ Observatoire des \\ Environnementaux (LMI OCE) \\ Changements \\ Institut de Recherche pour le Dévelopement \\ Campus Darcy Ribeiro, \\ Brasília. DF Brasil \\ ${ }^{*}$ Corresponding author: \\ kutter@ufpa.br
}

\section{Copyright}

This is an open-access article distributed under the terms of the Creative Commons Attribution License.

\section{RESUMO}

A Baía de Sepetiba possui uma riqueza de espécies de peixes (total de 148), assim como, uma vasta área de manguezais e inúmeras ilhas rochosas, importantes locais de reprodução da vida marinha. Este ambiente peculiar da costa brasileira contém um dos mais importantes centros industriais do sudeste do Brasil. Este local vem sendo impactado há décadas pelo lançamento de emissões industriais (outras) e efluentes com altas cargas metálicas. Os intervalos de concentração de metais no músculo de peixes das espécies Micropogonias furnieri, Genidens genidens, Cathorops spixii, Notarius grandicassis, Diapterus rhombeus, Selene vomer, Prionotus punctatus, Citharichthys spilopterus, Achirus lineatus, Trinectes Hypanistanus, Symphatus guttus : Al 0,02-555,9 $\mu \mathrm{g} \mathrm{g}^{-1} \mathrm{dw}$, As: 00002-20,1 $\mu \mathrm{g} \mathrm{g}^{-1} \mathrm{dw}, \mathrm{Cd}$ : $<0,0002-0,2 \mu \mathrm{g} \mathrm{g}^{-1} \mathrm{dw}, \mathrm{Cu}: 0,2-2,3 \mu \mathrm{g} \mathrm{g}^{-1} \mathrm{dw}, \mathrm{Fe}:<0,02-244,9 \mu \mathrm{g} \mathrm{g}^{-1} \mathrm{dw}, \mathrm{Zn}$ : $0,5-227,3 \mu \mathrm{g} \mathrm{g}^{-1} \mathrm{dw}$ e $\left.\mathrm{Pb}:<0,001-1,3 \mu \mathrm{g} \mathrm{g}^{-1} \mathrm{dw}\right)$. O teste de Kruskal-Wallis revelou diferenças significativas $(\mathrm{p}<0,05)$ nos teores de $\mathrm{As}, \mathrm{Cu}, \mathrm{Fe}, \mathrm{Pb}$ e $\mathrm{Zn}$ entre as espécies de peixes. Análises químicas do material particulado em suspensão durante a operação de dragagem revelaram as seguintes concentrações de metais $\mathrm{Al}\left(6059 \pm 6268 \mu \mathrm{g} \mathrm{g}^{-1}\right), \mathrm{Cd}\left(0,2 \pm 0,5 \mu \mathrm{g} \mathrm{g}^{-1}\right), \mathrm{Cu}(29$ $\left.\pm 29 \mu \mathrm{g} \mathrm{g}^{-1}\right), \mathrm{Zn}\left(332 \pm 892 \mu \mathrm{g} \mathrm{g}^{-1}\right)$ e $\mathrm{Pb}\left(52 \pm 70 \mu \mathrm{g} \mathrm{g}^{-1}\right)$. Os fatores de bioacumulação calculados a partir da fração de metais das frações biodisponíveis do sedimento e do metal total no material particulado em suspensão apresentaram valores inferiores aos do músculo dos peixes. $\mathrm{O}$ arsênio foi encontrado em níveis acima do limite máximo para consumo humano de acordo com a legislação brasileira. No entanto, a probabilidade estimada do risco de ingestão de metais via consumo de peixes mostrou que o consumo de todas as espécies apresentou baixo risco.

Palvras-chave: biodisponibilidade, fator de acumulação para biosedimento (BASF), estuário, contaminação, quociente de risco

\section{ABSTRACT}

Sepetiba Bay has a wealth of fish species (total 148) as well as a vast area of mangroves and numerous rocky islands, which are important sites of reproduction for marine life. This peculiar environment of the Brazilian coast hosts one of the most important industrial centres of south-eastern Brazil. This site has been impacted for decades by the release of industrial emissions and effluents with high metal loads by the steel industry. The ranges of metal concentrations in fish muscle from the species Micropogonias furnieri, Genidens genidens, Cathorops spixii, Notarius grandicassis, Diapterus rhombeus, Selene vomer, Prionotus punctatus, Citharichthys spilopterus, Achirus lineatus, Trinectes paulistanus, Symphurus tessellatus and Hypanus guttatus were measured (Al: 0.02-555.9 $\mu \mathrm{g} \mathrm{g}^{-1} \mathrm{~d}$.w., As: 0.0002-20.1 $\mu_{\mathrm{g} \mathrm{g}}{ }^{-1}$ d.w., Cd: $<0.0002-0.2 \mu \mathrm{g} \mathrm{g}^{-1}$ d.w., Cu: 0.2-2.3 $\mu \mathrm{g} \mathrm{g}^{-1}$ d.w., Fe: $<0.02-244.9 \mu \mathrm{g}$ $\mathrm{g}^{-1}$ d.w., Zn: 0.5-227.3 $\mu \mathrm{g} \mathrm{g}^{-1}$ d.w. and $\mathrm{Pb}:<0.001-1.3 \mu \mathrm{g} \mathrm{g}^{-1} \mathrm{~d}$.w.). The KruskalWallis test revealed significant differences $(\mathrm{p}<0.05)$ in the $\mathrm{As}, \mathrm{Cu}, \mathrm{Fe}, \mathrm{Pb}$ and $\mathrm{Zn}$ contents among fish species. The monitoring of suspended particulate 
matter during dredging operation revealed the mean metal values for $\mathrm{Al}$ $\left(6059 \pm 6268 \mu \mathrm{g} \mathrm{g}^{-1}\right), \mathrm{Cd}\left(0.2 \pm 0.5 \mu \mathrm{g} \mathrm{g}^{-1}\right), \mathrm{Cu}\left(29 \pm 29 \mu \mathrm{g} \mathrm{g}^{-1}\right), \mathrm{Zn}(332 \pm 892 \mu \mathrm{g}$ $\left.\mathrm{g}^{-1}\right)$, and $\mathrm{Pb}\left(52 \pm 70 \mu \mathrm{g} \mathrm{g}^{-1}\right)$. The results of bioaccumulation in fish calculated from the bioavailable sediment fractions and suspended particulate matter showed lower values than those in fish muscle. Arsenic was found at levels above the maximum limit for human consumption according to Brazilian legislation. However, the estimated probability and risk of metal intake via fish consumption showed that the consumption of all species presented low risk.

Keywords: bioavailability, biosediment accumulation factor (BSAF), estuary, contamination, hazard quotient

\section{INTRODUCTION}

Environmental degradation is led by the imbalance between the growth of the human population and industrial activity and environmental conservation. Metal pollution in coastal zones has been reported in diverse sites in Brazil (MIRLEAN et al., 2009; FONSECA et al., 2013; KIM et al., 2016), showing that the input of metals to aquatic ecosystems is affected by several urban and industrial sources, such as deforestation, untreated sewage, street run off, and chemical and petrochemical industry activities.

Sepetiba Bay has been impacted since the end of $1940 \mathrm{~s}$ by the first coal terminal serving the National Steel Company and by ore processing industries since the 1960s (BARCELLOS; LACERDA 1994). Fiszman et al. (1984) conducted the first study of metal contamination in the bay in the early 1980s. Furthermore, the increase in domestic wastewater discharged in the bay is an additional source of contamination (COPELAND et al., 2003). According to the 2010 census conducted by the Brazilian Institute of Geography and Statistics (IBGE, 2010), the Sepetiba Bay drainage basin has an estimated population of 403,643 individuals, many of whom live in houses without sewage treatment.

The presence of high metal concentrations, mainly zinc and cadmium, was reported as a consequence of activities from the steel industry (CARVALHO GOMES et al., 2009; RIBEIRO et al., 2013). The company discharged 24 tonnes year ${ }^{-1}$ of $\mathrm{Cd}$ and 3,660 tonnes year ${ }^{-1}$ of $\mathrm{Zn}$ in the bay until its closure after 30 years of activity, causing a nearly 200 -fold increase in the deposition of these metals in the coastal environment (BARCELLOS et al., 1991; BARCELLOS; LACERDA 1994). Additionally, arsenic (As) contamination in bay sediments is related to the arsenic trioxide $\left(\mathrm{As}_{2} \mathrm{O}_{3}\right)$ used for coal purification (MAGALHÃES et al., 2001). The discharge of effluent into the bay by Companhia Siderúrgica Mercantil Ingá
S.A. ceased in 2008 with the start of the remediation project, which concluded in 2015. During remediation, sediment from some areas with higher metal levels was removed by dredging, and the material was disposed of in an underwater confined disposal facility.

Although many cleaning actions have been performed in the bay, some areas still have high concentrations of metals in sediment (TONHÁ et al., 2020; MONTE el al., 2015). Moreover, dredging can remobilize and resuspend metals from the anoxic sediment layer, facilitating pollutant biodisponibilization (GOOSSENS; ZWOLSMAN 1996; MONTE el al., 2015). The frequent dredging to maintain navigability of the bay could represent a risk of metal contamination to marine life if sediment resuspension control is not undertaken during this activity.

Sediment toxicity evaluation has been employed using fish species as sentinel organisms (HARTL 2002; BERVOETS; BLUST 2003). Indeed, sentinel fish species monitoring is widely used to assess the degree of accumulation of pollutants and the effects on their health state (FITZGERALD et al., 1999; DE LA TORRE et al., 2000; NENDZA 2002; JIMENEZ-TENORIO et al., 2007).

Fish have been used to assess the environmental risk of metal contamination as they can assimilate it through their gills and diet (PHILLIPS 1977; VAN DER OOST et al. 2003). In the present study, the evaluation of fish contamination is necessary since this region has intense fishery activity. Considering that the consumption of contaminated fish represents a risk to human health, the aim of the present study was to evaluate metal concentrations in fish and calculate metal transference from the sediment and particulate matter of Sepetiba Bay during dredging. 


\section{MATERIALS AND METHODS}

\subsection{STUDY AREA}

Sepetiba Bay (Figure 1), which is situated $60 \mathrm{~km}$ west of Rio de Janeiro, has an area of $447 \mathrm{~km}^{2}$ during high tide and 419 $\mathrm{km}^{2}$ during low tide. The bay has an average depth of $6 \mathrm{~m}$ and has brackish water and seawater due to its connection with the Atlantic Ocean. The drainage basin is formed by the following rivers: Itingussu, Piração, Porto, Engenho Novo, Ita, Cação, Piraquê, Guandu, Guarda and São Francisco. The São Francisco River is responsible for $86 \%$ of the freshwater input to the bay (BARCELLOS et al. 1997; MOLISANI et al., 2006).

Wastewater from the cities of Itaguaí, Mangaratiba, Japeri and Miguel Pereira, which corresponds to a population of 403,643 inhabitants (IBGE 2010), flows into the bay, as does some of the effluent from Rio de Janeiro, Nova Iguaçu, Rio Claro, Piraí, Engenheiro Paulo de Frontin and Vassouras.
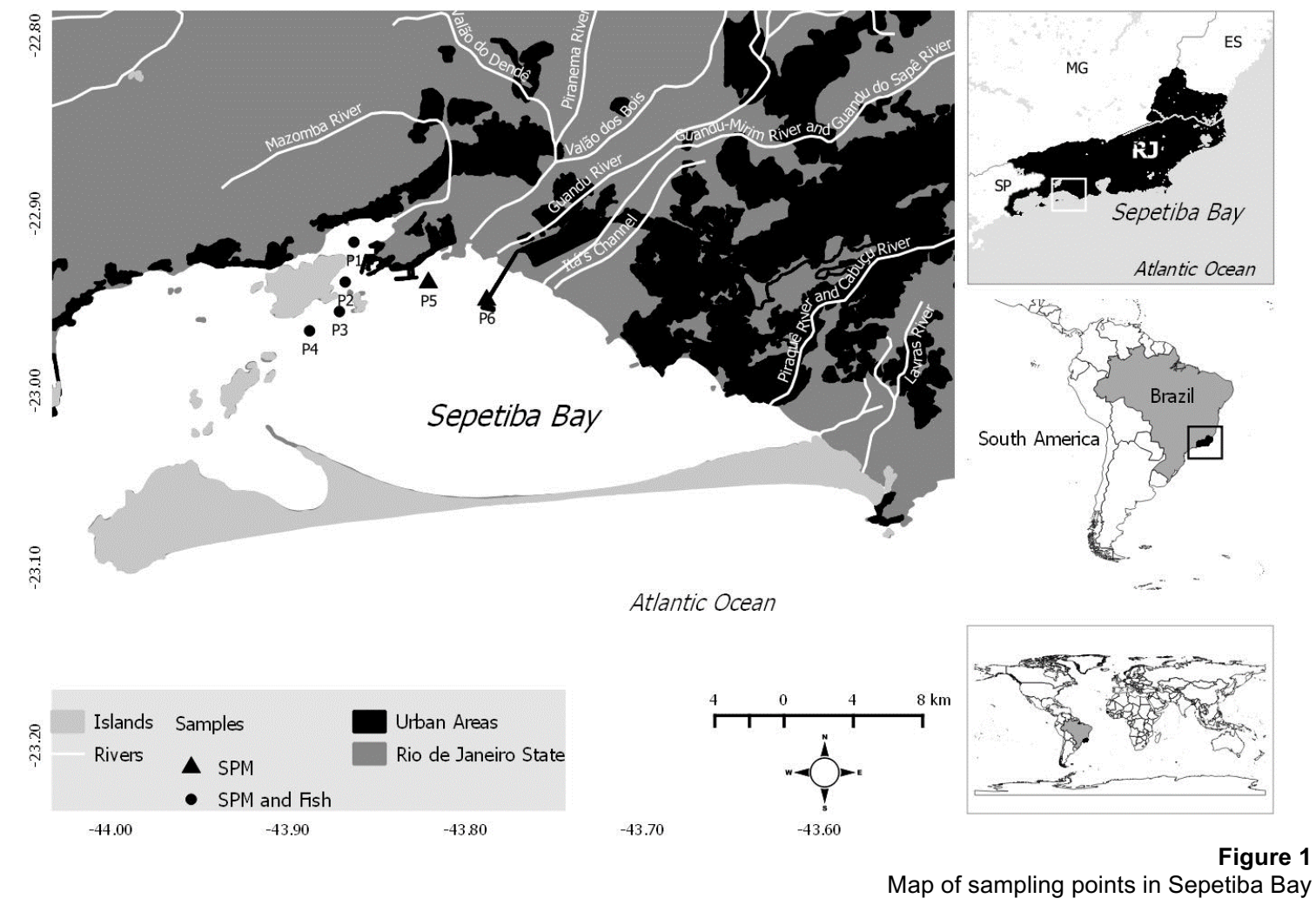

\subsection{FISH SAMPLING}

Fish sampling was carried out by horizontal trawling using $20 \mathrm{~mm}$ mesh in the middle of the net and $10 \mathrm{~mm}$ mesh in the funnel $(10 \mathrm{~m}$ in length with a mouth opening of $3 \mathrm{~m}$ in width). Four sites were sampled (Figure 1). Trawling was conducted in circles of $30 \mathrm{~m}$ for 20 minutes, with the coordinates corresponding to the centre of the cycle. The collected fish were cleaned with distilled water and kept frozen in an icebox until arrival at the laboratory, where the species were identified, and biometric (weight and total length) data were collected.

Samples of the caught fish species, which included Micropogonias furnieri (31), Genidens genidens (16), Cathorops spixii (4), Notarius grandicassis (3), Prionotus punctatus (11), Citharichthys spilopterus (9), Achirus lineatus (3), Trinectes paulistanus (3), Symphurus tessellatus (7), Hypanus guttatus (3), Diapterus rhombeus (13) and Selene vomer (3), were double bagged in separate clean plastic bags, sealed and labelled accordingly.

Among the fish biological parameters, the morphometric traits and condition factor $(\mathrm{K})$ were assessed. Individual biometry was carried 
out to determine the total length $(\mathrm{Lt}, 0.3 \mathrm{~cm}$ precision) and total weight ( $\mathrm{Wt}, 0.005 \mathrm{~g}$ precision).

Afterwards, the fish were dissected using a scalpel to remove the muscle, and the tissues were lyophilized $(72$ h) until subsequent homogenization (maceration in agate mortar) and subsequently subjected to chemical treatment to determine the metal concentrations.

Among the caught species, S. tessellatus and $P$. punctatus remain within the bay during all life cycle phases (estuarine resident). The other species leave the estuary during the adult phase, returning to it only during periods of foraging and spawning. In relation to food habits, most of the studied species were carnivorous, with the exception of three omnivorous species ( $G$. genidens, $C$. spixii, and $N$. grandicassis).

The health status from the length-weight relationship of the fish samples was calculated using the Fulton condition factor (WILLIAMS, 2000; RANNEY et al., 2010), which was calculated by the following equation:

$$
\mathrm{K}=100 \mathrm{~W} / \mathrm{L}^{3} \text { (Equation 1) }
$$

where $\mathrm{W}$ is the total body weight of the fish $(\mathrm{gm})$ and $\mathrm{L}$ is the total length of the fish $(\mathrm{cm})$. Fulton's $\mathrm{K}$ was categorized as follows: $\mathrm{K}=1$ : condition is poor, $\mathrm{K}=1.2$ : condition is moderate, and $\mathrm{K} \geq 1.40$ : condition is relatively good.

\subsection{SUSPENDED PARTICULATE MATTER (SPM) SAMPLING}

In the field, surface water was collected using a Van Dorn bottle. The samples were collected monthly in 2014 (January to June) at six points (Figure 1). The water was stocked in acid-cleaned bottles $\left(\mathrm{HNO}_{3}, 2 \%\right)$ (SHAFER; OVERDIER, 1995). After this, in the laboratory, the water was filtered in a

\subsection{METAL ANALYSIS}

Fish tissue and suspended particulate matter (SPM) were digested in a microwave (BERGHOF-SPEEDWAVE 4) (0.3 g dry muscle $+2 \mathrm{~mL} \mathrm{H}_{2} \mathrm{O}_{2}+5 \mathrm{~mL} \mathrm{HNO}_{3}$ ) (suspended particulate matter $+6 \mathrm{~mL}$ $\mathrm{HNO}_{3}$ ). The metal concentrations were analysed with an ICP-MS (XSeries II, Thermo Fisher). The quality control analysis

\subsection{METAL BIOCONCENTRATION FACTOR}

To evaluate metal bioaccumulation by the fish, the biosediment accumulation factor (BSAF) (USERO et al., 2005), which is defined as the ratio between the metal concentration in the organism and that in the sediment or suspended particulate matter (LAFABRIE et al., 2007; WANICK et al., 2013; DIAS; NAYAK 2016), was calculated. vacuum system using membranes of acetate cellulose with $0.45 \mu \mathrm{m}$ pores that were precleaned in acid and Milli-Q water. The membrane with suspended particulate matter was oven dried for posterior metal analysis. was verified through blank samples and a certified reference material (NIST SRM$1566 \mathrm{~B}$, oyster tissue). The metals Al (115.3\%), Cd (87.2\%), Fe (112.1\%), Pb (93.7\%), Cu (110.0\%), Zn (107.6\%) and As $(105.8 \%)$ showed good to excellent recoveries.
The BSAF was only calculated for the fish species with large numbers of samples (G. genidens, M. furnieri, D. rhombeus, and $P$. punctatus). We used the data in the literature on bioavailable metals in the sediment to calculate the BSAF (MONTE et al., 2015; RODRIGUES et al., 2017) (Table 1). For the suspended particulate matter, the metal concentration data found in the present study were applied.

\subsection{ASSESSMENT OF HUMAN HEALTH RISK FROM METAL-CONTAMINATED FISH INTAKE}

Two methodologies were adopted to assess the risk of contamination through the ingestion of fish contaminated with metals.
First, the total concentration of metals in the muscle of the investigated fish species was compared to national (ANVISA) and 
international (FAO, European Commission) regulatory values. The second methodology was to estimate the probability and risk from metal intake by means of the assessment of the hazard quotient (HQ) according to the following equation (U.S. EPA, 2002):

$$
H Q=\frac{A D D}{R f D}(\text { Equation } 2)
$$

where ADD is the average daily dose and $\mathrm{RfD}$ is the oral reference dose. The ADD is calculated by the equation:

$$
A D D=\frac{C * I R * E F * E D}{B W * A T} \quad \text { (Equation 3) }
$$

where $\mathrm{C}$ is the average metal concentration in fish tissue, IR is the human ingestion rate (the control population has a mean Brazilian fish intake (IBGE 2010) of $10 \mathrm{~kg}$ year $^{-1}$ or $0.027 \mathrm{~kg} \mathrm{day}^{-1}$ and the fishing population has an intake of $\left.0.2 \mathrm{~kg} \mathrm{day}^{-1}\right)$, EF is the exposure frequency (control population: 48 days per year and fishing population: 365 days per year), ED is the average exposure duration (years, 30 years), BW is the average body weight (mean for Brazilian men and women $>20$ years of $67 \mathrm{~kg}$ ) (IBGE 2010) and AT is the average time (AT $=365 \times \mathrm{EDd})$. $\mathrm{RfD}$ is the reference dose $(\mathrm{mg} / \mathrm{kg} /$ day) (inorganic As: $0.0003 \mathrm{mg} / \mathrm{kg} /$ day; Cd: $0.001 \mathrm{mg} / \mathrm{kg} /$ day; $\mathrm{Cu}: 0.04 \mathrm{mg} / \mathrm{kg} / \mathrm{day} ; \mathrm{Pb}: 0.003 \mathrm{mg} / \mathrm{kg} /$ day; and $\mathrm{Zn}: 0.3 \mathrm{mg} / \mathrm{kg} /$ day) (U.S EPA 1991).

In relation to As, we calculated the concentration of inorganic As (the most toxic species) considering that 2 to $30 \%$ of the total As in fish muscle is in the inorganic species according to Kirby and Maher 2002.

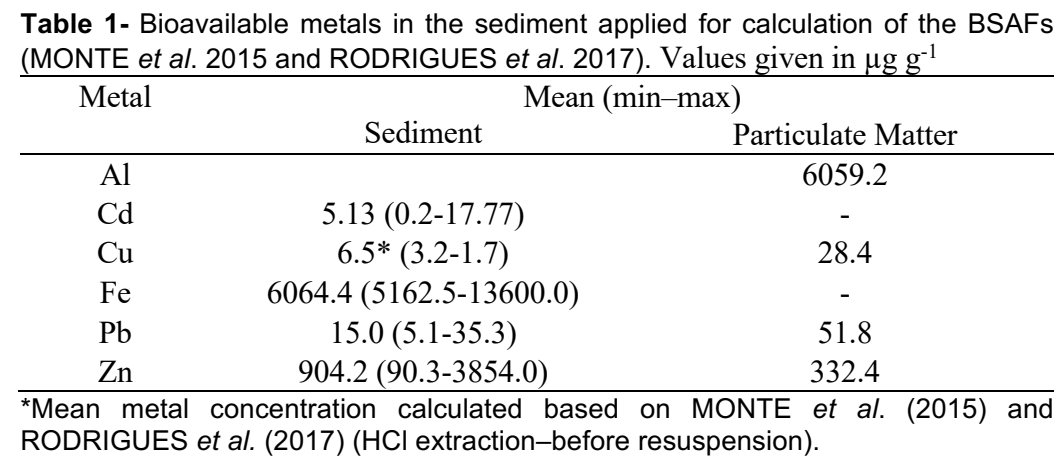

\section{RESULTS}

The SPM concentration distribution collected in 2014 varied from $2.86 \pm 1.81 \mathrm{mg} \mathrm{L}^{-1}$ in March to $34.36 \pm 13.04 \mathrm{mg} \mathrm{L}^{-1}$ in February on average. In general, the data presented a tendency towards higher values close to the mouth of the São Francisco channel and Guandu River. Rodrigues et al. (2009) observed values of suspended particulate matter similar to those found by this study, which varied from 11.35 to $32.2 \mathrm{mg} \mathrm{L}^{-1}$ in the wet period (January) and $7.32 \mathrm{mg} \mathrm{L}^{-1}$ to $6.36 \mathrm{mg} \mathrm{L}^{-1}$ in the dry period (June).

During sampling, the 106 specimens from 12 species were collected. Of this total, $70 \%$ of individuals were represented by 4 species from 4 different families: M. furnieri (Sciaenidae), 29.2\%; G. genidens (Ariidae), 15.1\%; D. rhombeus (Gerreidae), 12.3\%; and P. punctatus (Triglidae), 10.4\%.

The condition factor is an estimation of the general well-being of fish (JONES et al., 1999). It is based on the hypothesis that heavier individuals of a given length are in better condition than less weighty individuals (BAGENAL; TESCH, 1978). In general, the fish collected during the winter season showed a mean total length that ranged from $10.4 \pm 2.7$ $\mathrm{cm}$ (D. rhombeus) to $24.0 \pm 1.8 \mathrm{~cm}$ (H. gutattus) and a mean total weight that ranged from $17.2 \pm 17.0 \mathrm{~g}$ (D. rhombeus) to $517.3 \pm 114.0 \mathrm{~g}$ (H. gutattus).

Freire et al. (2020) observed 130 specimens of the catfish $G$. genidens that were caught in the spring months of 2013 and 2014 in three bays of the Rio de Janeiro state (including Sepetiba Bay) and recorded a mean total length of 19.1-21.4 cm, which was similar to that found in this study $(13-26 \mathrm{~cm})$, and a mean total weight range of 72.2-89.5 g, which was less than that reported in this study (19.3-132.3 g).

Similar to that observed by Freire et al. (2020), in general, the poor physiological states of the fish indicated by Fulton's Q possibly reflected the extremely poor environmental 
quality of Sepetiba Bay; the fish showed an average general condition factor of 1.2, with the exception of $H$. guttata, which had a factor of $3.7(\mathrm{n}=3$ specimens $)$.

This worsening of the quality of the bay's environment likely increased the exposure time of the fish to the effects of suspended particulate material with metals. Moreover, dredging activities can also have adverse effects on

\subsection{METALS IN FISH}

The statistical analysis of the KruskalWallis test did not show significant differences $(p>0.05)$ in $\mathrm{Al}$ and $\mathrm{Cd}$ concentrations among the fish species (Figure 2a-c). In addition, significant differences $(\mathrm{p}<0.05)$ in the $\mathrm{As}, \mathrm{Cu}, \mathrm{Fe}, \mathrm{Pb}$ and $\mathrm{Zn}$ distributions among the species were observed (Figure 2b, d-g).

Arsenic had the most variable distribution among the fish species, showing significant differences $(\mathrm{p}<0.05)$ for $D$. rhombeus x (C. spixii, G. genidens and $M$. furnieri); $G$. genidens x (C. spilopterus, $P$. punctatus, $S$. vomer and $S$. tessellatus); and $M$. furnieri $\mathrm{x}$ (C. spilopterus and $S$. tessellatus) (Figure 2b). The $\mathrm{Cu}$ concentration presented significant differences $(\mathrm{p}<0.05)$ among P. punctatus $\mathrm{x}$ ichthyofauna by reducing food abundance. The removal of sediments leads to the death of the benthic fauna and the increased water column turbidity, reducing primary productivity, although temporary, reduces primary productivity. In addition, discharges of domestic effluents with a range of toxic substances can have synergistic effects on aquatic fauna.

(D. rhombeus, M. furnieri, N. grandicassis, and $S$. vomer), $N$. grandicassis x ( $S$. tessellatus), and $S$. vomer x (S. tessellatus) (Figure 2d).

Four fish species showed differences in Fe concentrations: A. lineatus x (H. guttatus and $P$. punctatus) and $H$. guttatus $\mathrm{x}(N$. grandicassis) (Figure 2e). Only G. genidens $\mathrm{x}$ (D. rhombeus) presented a significant difference in the $\mathrm{Pb}$ concentration (Figure 2f). The largest difference in $\mathrm{Zn}$ concentrations was found in $D$. rhombeus $\mathrm{x}$ (H. guttatus, G. genidens, M. furnieri, $P$. punctatus and $S$. tessellatus), followed by $N$. grandicassis $\times(S$. tessellatus, $P$. punctatus and $H$. guttatus) and C. spilopterus x (H. guttatus and P. punctatus) (Figure $2 \mathrm{~g}$ ).

\subsection{METALS IN SUSPENDED PARTICULATE MATTER (SPM)}

Collin and Hart (2015) deduced that one of the most commonly observed behaviours by fish in response to elevated suspended sediment is the avoidance of turbid water. On the other hand, it is worth noting that not only the increase in water turbidity but also the exposure time has also produced long-term shifts in local abundance and community composition.

In the studied period, points $\mathrm{P} 1$ to $\mathrm{P} 5$ were influenced by dredging operations. Although point P6 is not directly influenced by dredging operations, it receives the discharge of the São Francisco and Guandu Rivers, which represents more than $86 \%$ of the watershed input. During 2014, 3.7 million $\mathrm{m}^{3}$ of dredged material was removed from Sepetiba Bay and dumped offshore in a licensed disposal area 6 nautical miles outside of the bay. It is known that dredging operations increase the particulate matter in the area due to sediment resuspension.
The months of January and February showed higher mean concentrations of Al, $\mathrm{Cu}$ and $\mathrm{Pb}$ in suspended particulate matter than other sampling periods. This concentration can be the result of dredging operations in addition to the rainy season, consequently resulting in the increase of runoff and river discharge from the watershed to the bay.

Except for points P1 to P5 and P2, P3 and $\mathrm{P} 5$ in January and April, respectively, in the other months sampled, the $\mathrm{Cd}$ concentrations were below the detection limit $\left(<0.0002 \mu \mathrm{g} \mathrm{g}^{-1}\right)$. In the month of June, $\mathrm{Pb}$ and $\mathrm{Cu}$ at points $\mathrm{P} 2$ to $\mathrm{P} 6$ showed concentrations $<0.001 \mu \mathrm{g} \mathrm{g}^{-1}$ and $<0.002 \mu \mathrm{g}$ $\mathrm{g}^{-1}$, respectively (Figure 3 ).

Higher mean Zn concentrations were observed in February and June (Figure 3). In March and April, approximately $50 \%$ of the samples presented $\mathrm{Zn}$ concentrations $<0.02 \mu \mathrm{g} \mathrm{g}^{-1}$. 


\subsection{BIOSEDIMENT ACCUMULATION FACTOR}

The fish species with the highest BSAFs for particulate matter for all analysed metals was $D$. rhombeus, while those for the

\section{DISCUSSION}

\subsection{METALS IN FISH}

The similarity of $\mathrm{Al}$ and $\mathrm{Cd}$ distributions among the fish species can be related to the fact that these are non-essential elements, and therefore, organisms have physiological mechanisms for non-assimilation and/or efficient excretion (WOOD et al., 2012a, b). Furthermore, the differences in the metal (Fe, $\mathrm{Zn}, \mathrm{Cu}$ ) distributions among the species can be related to the essential nature of these elements (UTHUS 1992; WOOD et al $2012 \mathrm{a}, \mathrm{b})$, the specific physiological requirements of the species and food habits.

Some studies that have investigated the food habits of ichthyofauna in Sepetiba Bay have indicated that the index of relative importance for the studied species included the following organisms: Polychaeta (for $M$. furnieri, A. lineatus, and T. paulistanus), Polychaeta and Crustacea (for G. genidens, $P$. punctatus, and S. tessellatus), Copepoda, Ostracods and Polychaeta (for C. spixii and D. rhombeus), Teleostei (for C. spilopterus) and Isaeidae and Polychaeta (for $S$. tessellatus) (GUEDES; ARAÚJO 2008; GUEDES et al., 2015). Some investigations on the Brazilian coast have indicated that the main food items for species are as follows:

\subsubsection{ALUMINIUM}

The high Al concentrations in fish are related to gill inflammation and increased mucus production (PLAYLE et al. 1989; WITTERS et al. 1991). In addition, this metal reduces the growth rate and reproduction success (WOOD et al 2012b). In humans, Al accumulation in the brain has been suggested to be involved in the development of neurodegenerative disorders, amyotrophic lateral sclerosis and Alzheimer's disease (BONDY 2010). The average Al concentration found in the $M$. furnieri species in the present study $\left(1.7 \mu \mathrm{g} \mathrm{g}^{-1}\right.$ w.w.) was half that found $\left(3.8 \mu \mathrm{g} \mathrm{g}^{-1}\right.$ w.w.) by Carneiro et al. (2011) and an order of magnitude lower than that $\left(76.1 \mu \mathrm{g} \mathrm{g}^{-1} \mathrm{w} . \mathrm{w}.\right)$ observed by Medeiros et al. (2012) in fish
BSAFs in sediment were G. genides (for $\mathrm{Cu}$, $\mathrm{Fe}, \mathrm{Pb}$ ) and $P$. punctatus (for $\mathrm{Zn}$ ) (Table 2).

S. vomer (crustaceans and fish) (HÖFLING et al., 1998), H. guttatus (crustaceans and molluscs) (CARQUEIJA et al., 1995; SILVA et al., 2001), and $N$. grandicassis (crustaceans) (MENDES; BARTHEM 2010).

In the present study, considering the food items reported in the literature, we observed the importance of diet in metal accumulation in fish muscle (supplementary material S1). For example, D. rhombeus, which consumes zooplankton (copepods), showed lower As and $\mathrm{Pb}$ concentrations and higher $\mathrm{Cu}$ and $\mathrm{Zn}$ concentrations than other species whose food included Polychaeta and crustaceans. According to the compilation shown in supplementary material S1, molluscs had the highest metal concentrations and are an important group in the transfer of metals to the fish community.

Furthermore, to assess the potential risk of human consumption of these fish, the metal concentrations were calculated for wet weight considering an average moisture of $80 \%$ in fish muscle (MURRAY; BURT 1983).

(M. furnieri) purchased at the São Pedro fish market in Niterói in south-eastern Brazil. Unfortunately, in that study, the authors did not determine the origin of the fish purchased in the market. The species Symphurus tessellatus showed a higher mean $\mathrm{Al}$ concentration $\left(20.3 \mu \mathrm{g} \mathrm{g}^{-1} \mathrm{w} . \mathrm{w}.\right)$ in this study than the one $\left(9.4 \mu \mathrm{g} . \mathrm{g}^{-1}\right.$ w.w. $)$ conducted on the Macaé coast of southeastern Brazil (CARVALHO et al., 2000).

In Sepetiba Bay, the discharge of rivers and the effluent from the water treatment Guandu station for the human water supply of Rio de Janeiro (second largest water treatment plant in the world, namely, the ETA-Guandu) were the most likely sources of Al to the bay (Professor Silva-Filho personal communication). 


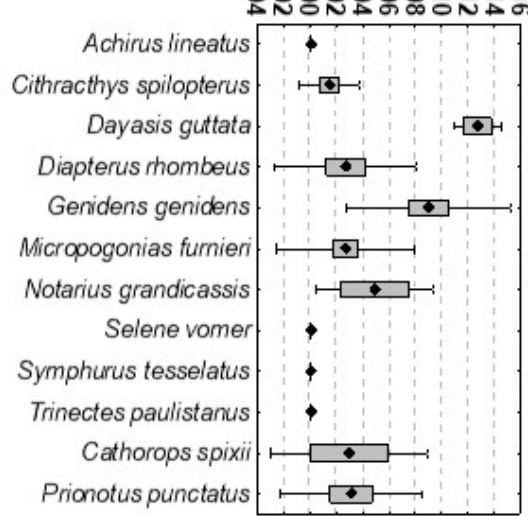

$\mathrm{Cu}$ ( $\mu \mathrm{g} \cdot \mathrm{g}^{-1} \mathrm{dry}$ weight)

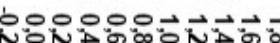

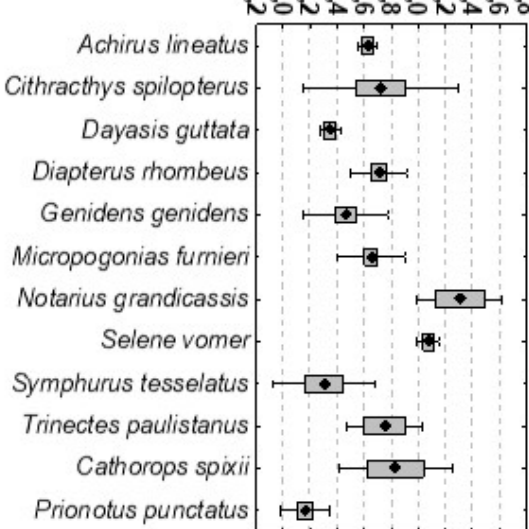

$\mathrm{Pb}$ ( $\mu \mathrm{g} \cdot \mathrm{g}^{-1}$ dry weight)

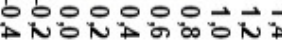

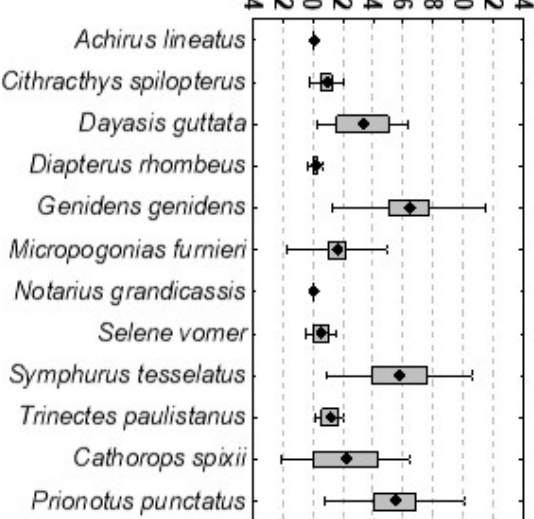
Cithracthys spilopterus

Dayasis guttata

Diapterus rhombeus

Genidens genidens

Micropogonias furnieri

Notarius grandicassis

Selene vomer

Symphurus tesselatus

Trinectes paulistanus

Cathorops spixii

Prionotus punctatus

$\mathrm{Zn}$ ( $\mu \mathrm{g} \cdot \mathrm{g}^{-1}$ dry weight)

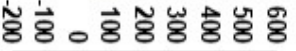
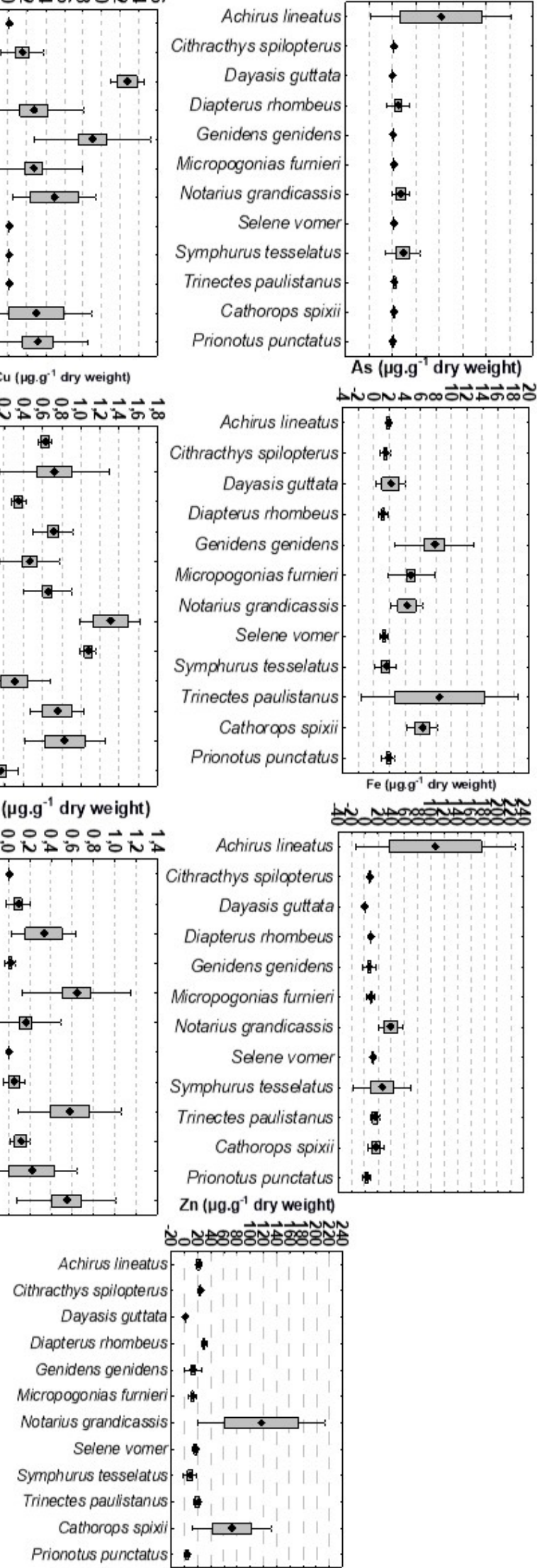

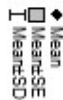

Figure 2

Metal distribution in fish species of Sepetiba Bay 


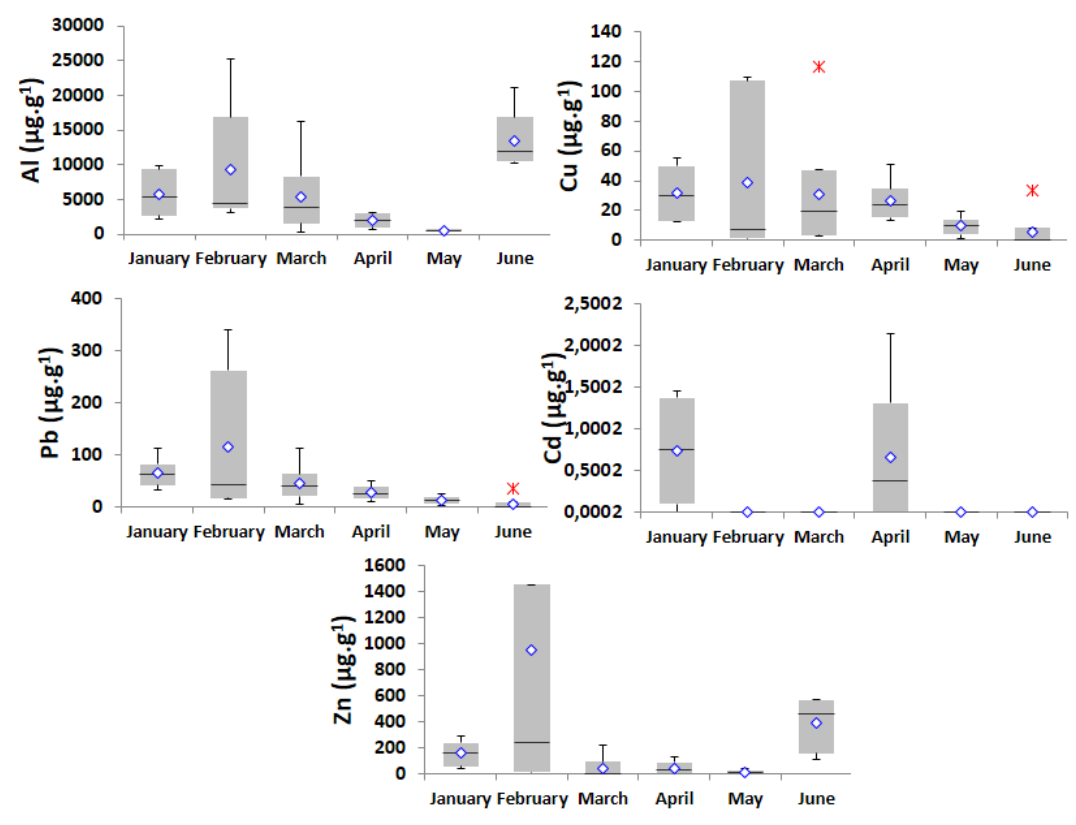

Figure 3

Metals in SPM: (diamond) mean, (-) median, and $\left({ }^{*}\right)$ outlier

\begin{tabular}{|c|c|c|c|c|c|c|c|c|}
\hline \multirow[t]{2}{*}{ Metal } & \multicolumn{4}{|c|}{ BSAF (sediment bioavailability) } & \multicolumn{4}{|c|}{ BSAF (particulate matter) } \\
\hline & 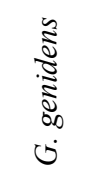 & 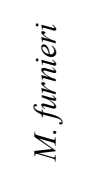 & 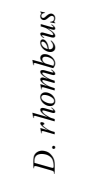 & 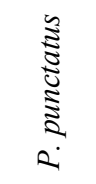 & 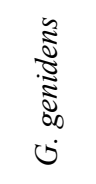 & 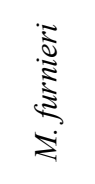 & 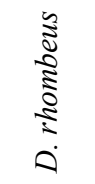 & 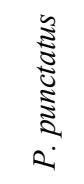 \\
\hline $\mathrm{Al}$ & - & - & - & - & 0.001 & 0.001 & 0.004 & 0.003 \\
\hline $\mathrm{Cd}$ & 0.02 & 0.02 & 0.02 & 0.02 & - & - & - & - \\
\hline $\mathrm{Cu}$ & 0.07 & 0.1 & 0.11 & 0.05 & 0.02 & 0.02 & 0.03 & 0.01 \\
\hline $\mathrm{Fe}$ & 0.003 & 0.002 & 0.001 & 0.002 & - & - & - & - \\
\hline $\mathrm{Pb}$ & 0.06 & 0.05 & 0.01 & 0.05 & 0.02 & 0.01 & 0.003 & 0.01 \\
\hline $\mathrm{Zn}$ & 0.01 & 0.01 & 0.03 & 0.004 & 0.04 & 0.04 & 0.09 & 0.01 \\
\hline
\end{tabular}

\subsubsection{ARSENIC}

Arsenic accumulation in fish tissue can cause a reduction in growth and fertility as well as skin lesions and developmental disorders (WOOD et al., 2012b). The immunotoxic effects in fish from chronic exposure to this element have been demonstrated (DATTA et al., 2009).

Higher As concentrations in the sediments were reported in Sepetiba Bay (MAGALHÃES et al., 2001). The mean As concentration in tissue observed in the present study for M. furnieri $\left(1.0 \mu \mathrm{g} . \mathrm{g}^{-1} \mathrm{~W} . \mathrm{w}\right)$ was close to that reported in estuaries from

\subsubsection{CADMIUM}

Elevated concentrations of $\mathrm{Cd}$ in fish are associated with ion imbalances, the
South America (south-eastern Brazil $1.2 \mu \mathrm{g}$ $\mathrm{g}^{-1}$ w.w. (MEDEIROS et al., 2012) and Uruguay (1.2 $\mu \mathrm{g} \mathrm{g}^{-1}$ w.w. (CORRALES et al., 2016)). The $C$. spixii species from Sepetiba (1.2 $\mu \mathrm{g} \mathrm{g}^{-1}$ w.w.) presented half of the As concentration found in this species from Paranaguá (3.4 $\mu \mathrm{g} \mathrm{g}^{-1}$ w.w.) (southeastern Brazil) (ANGELI et al., 2013). In contrast, the $G$. genides in the present study (1.6 $\mu \mathrm{g} . \mathrm{g}^{-1}$ w.w.) were enriched in As in comparison to those from Paranaguá $(1.0 \mu \mathrm{g}$ $\mathrm{g}^{-1}$ w.w.) (ANGELI et al., 2013).

reduction in growth and reproduction, immunosuppression and endocrine 
disruption (WOOD et al., 2012b). Human diseases related to $\mathrm{Cd}$ are ionic imbalances in serum and osteoporosis (YOUNESS et al., 2012).

Cadmium contamination in sediment was reported for Sepetiba Bay (BARCELLOS; LACERDA 1994). According to the cited authors, $\mathrm{Cd}$ accumulation was related to the operation of Mercantil Ingá, which processes iron ore. The results of the present study showed a low concentration of this element. The highest concentration was approximately $0.02 \mu \mathrm{g} . \mathrm{g}^{-1} \mathrm{~W} . \mathrm{w}$. in $C$. spixii,

\subsubsection{COPPER}

Copper is an essential trace element for all biological organisms from bacterial cells to humans and is a key constituent of metabolic enzymes (CRAIG et al., 2007, FESTA; THIELE, 2011)

Elevated $\mathrm{Cu}$ exposure in fish can cause olfactory inhibition, a reduction in neuron sensitivity in the lateral line, an increase in cortisol levels and catabolism of proteins, a reduction in the swimming capacity and immunosuppression (WOOD et al., 2012a). Excess $\mathrm{Cu}$ can cause hepatic diseases in humans.

The $\mathrm{Cu}$ concentration $\left(0.06 \mu \mathrm{g} \mathrm{g}^{-1}\right.$ W.w. $)$ for $H$. gutattus from Sepetiba Bay was one order of magnitude lower than the coast of

\subsubsection{IRON}

Iron concentrations vary by fish species (SHIAU; SU 2003). This characteristic was also observed in the present study. The physiological actuation of $\mathrm{Fe}$ in vertebrates is related to its participation in respiratory pigments, cytochrome c-oxidase, DNA synthesis and the immune system. Elevated $\mathrm{Fe}$ concentrations can cause alterations in the liver and kidneys as well as reductions in growth and immunosuppression.

\subsubsection{LEAD}

The main source of $\mathrm{Pb}$ in the aquatic environment is the atmospheric deposition of particulate material from the burning of fossil fuels (RENBERG et al., 2000). Pb addition in fuel has been banned in Brazil since the 1990s, but this metal is still used in other activities, such as ship painting. Furthermore, local inhabitants burn domestic waste (personal observation),
D. rhombeus, P. punctatus, S. tessellatus, and $H$. guttatus.

On the Brazilian coast, the following values have been reported: $0.0004-0.07 \mu \mathrm{g}$ $\mathrm{g}^{-1}$ w.w. for $M$. furnieri (KEHRIG et al., 2007; MEDEIROS et al., 2012; NIENCHESKI et al., 2014), 0.002-0.7 $\mu \mathrm{g}$ g ${ }^{1}$ w.w. for $C$. spixii (BARBIERI et al., 2010; AZEVEDO et al., 2012; ANGELI et al., 2013; NIENCHESKI et al., 2014), and 0.06 $\mu \mathrm{g} \mathrm{g}^{-1} \mathrm{~W} . \mathrm{w}$. for H. gutattus (CARVALHO et al., 2000).

Macaé, RJ, Brazil (1.1 $\mu \mathrm{g} \mathrm{g}^{-1} \quad$ w.w.) (CARVALHO et al., 2000). The species $M$. furnieri showed $\mathrm{Cu}$ concentrations lower than those in other coastal regions of Brazil: Guanabara Bay, $0.6 \mu \mathrm{g} \mathrm{g}^{-1}$ w.w. (KEHRIG et al., 2007) and Patos Lagoon, 0.06-1.1 $\mu \mathrm{g} \mathrm{g}$ ${ }^{1}$ w.w. (NIENCHESKI et al., 2014). The species $C$. spixii and $G$. genidens from Sepetiba showed the lowest $\mathrm{Cu}$ accumulations of $0.2 \mu \mathrm{g} \mathrm{g}^{-1}$ w.w. and 0.08 $\mu \mathrm{g} \mathrm{g}^{-1}$ w.w., respectively. In other Brazilian estuarine environments, the concentrations in these species range from $0.07-0.32 \mu \mathrm{g} \mathrm{g}^{-1}$ w.w. (AZEVEDO et al., 2012; ANGELI et al., 2013; NIENCHESKI et al., 2014).

Data from the literature have described the $\mathrm{Fe}$ concentrations in $M$. furnieri from Guanabara Bay at $2.1 \mu \mathrm{g} \mathrm{g}^{-1}$ w.w. (KEHRIG et al., 2007), which is the same order of magnitude found in the present study $(2.4 \mu \mathrm{g}$ $\mathrm{g}^{-1}$ w.w.). Only $S$. tessellatus showed Fe concentrations that were two times higher (12.2 $\mu \mathrm{g} \mathrm{g}^{-1}$ w.w.) in Sepetiba Bay than in Macaé, RJ (6.3 $\mu \mathrm{g} \mathrm{g}^{-1}$ w.w.) (CARVALHO et al., 2000).

which is carried to tributary rivers running to the bay.

Fish exposed to $\mathrm{Pb}$ showed histological alterations in the liver and kidneys, reductions in growth and immunosuppression (MUNOZ et al., 2015). In addition, humans exposed to $\mathrm{Pb}$ develop kidney disease, haematological disorders and neuronal disturbances (loss of memory 
and cognitive impairment) (SILBERGELD et al., 2000).

Higher $\mathrm{Pb}$ concentrations were observed in two catfish species, $G$. genidens and $C$. spixii (Figure 2). These concentrations can be associated with the feeding behaviour of

\subsubsection{ZINC}

Zinc is an essential element in fish. However, exposure to higher concentrations can produce hyperplasia and higher mucus secretion in gills. $\mathrm{Zn}$ participated in the metabolism of proteins, nucleic acids, carbohydrates and lipids. $\mathrm{Zn}$ also acts in the immunologic system and neurotransmission (WOOD et al., 2012, a). In humans, Zn acts as an enzyme cofactor. Furthermore, higher concentrations can alter $\mathrm{Cu}$ and $\mathrm{Fe}$ metabolism, reduce high-density protein in serum and depress the immune system.

High concentrations of $\mathrm{Zn}\left(9.7 \mu \mathrm{g} \mathrm{g}^{-1}\right)$ were reported in $M$. furnieri from Sepetiba Bay (CARNEIRO et al., 2011) that were

\subsection{HUMAN HEALTH RISK ASSESSMENT}

This study indicated that $\mathrm{Cd}$ and $\mathrm{Pb}$, which are non-essential metals, were below the permissible limit suggested by the European Commission and ANVISA (Table 3).

For As only, ANVISA established $(1 \mu \mathrm{g}$ $\mathrm{g}^{-1}$ w.w.) the maximum values for human consumption. The concentrations in $G$. genidens $\left(1.6 \pm 1.0 \mu \mathrm{g} \mathrm{g}^{-1} \mathrm{w} . \mathrm{w}\right), C$. spixii $\left(1.2 \pm 0.4 \mu \mathrm{g} \mathrm{g}^{-1} \mathrm{w} . \mathrm{w}\right)$ and $T$. paulistanus $\left(1.7 \pm 2.0 \mu \mathrm{g} \mathrm{g}^{-1}\right.$ W.w) found in Sepetiba Bay exceeded this limit. This metal presents a variety of chemical forms, and arsenobetaine is the most abundant in fish tissue (KIRBY; MAHER 2002; VILLALOJO et al., 2002). Arsenobetaine has been identified as a major water-soluble As compound in the tissues of marine organisms (EDMONDS; FRANCESCONI, 1993).

Other studies have reported As concentrations in the tissues of C. spixii, $G$. genidens and M. furnieri from the Brazilian coast that were above the human consumption limit established by the ANVISA (MEDEIROS et al., 2012; ANGELI et al 2013). According to Mirlean et al. (2011, 2012), sediments from the south-eastern Brazilian coast are naturally enriched in As due to detritus from the species, which are bottom feeders consuming contaminated sediments from the bay. Higher values $\left(11.2 \mu \mathrm{g} \mathrm{g}^{-1}\right.$ w.w.) of this metal in C. spixii are reported in the north-eastern region of the Brazilian coast (BARBIERI et al., 2010).

approximately 3 times higher than the present study (2.4 $\mu \mathrm{g} \mathrm{g}^{-1}$ w.w.). This species presents a large variation in $\mathrm{Zn}$ along the Brazilian coast (0.4-8.1 $\mu \mathrm{g} \mathrm{g}^{-1}$ w.w. in Patos Lagoon (NIENSCHESKI et al., 2014) and $3.2 \mu \mathrm{g} \mathrm{g}^{-1} \mathrm{w}$.w. in Guanabara Bay (KEHRIG et al., 2007)). The same variation was found in C. spixii $\left(4.3-15.6 \mu \mathrm{g} \quad \mathrm{g}^{-1} \quad\right.$ w.w. (BARBIERI et al., 2010; AZEVEDO et al., 2012; ANGELI et al., 2013; NIENSCHESKI et al., 2014). In Cananéia in southeastern Brazil, there are higher $\mathrm{Zn}$ concentrations in the muscle of $C$. spixii from the pristine area (1.5 times higher than the polluted area) (AZEVEDO et al., 2012).

geniculate calcareous algae and iron oxyhydroxides, which are rich in As. Moreover, Sepetiba Bay possesses historical anthropogenic As contamination (MAGALHÃES et al., 2001).

Table 4 shows the HQ for all species investigated. As reported by Horta et al. (2011), the fishing population, due to the consumption of a greater amount of fish, has a higher risk of metal intake. Compared to the control population, the risk of metal intake in the fishing population increased by 56 times for inorganic $\mathrm{As}, \mathrm{Cu}$ and $\mathrm{Zn}, 62$ times for $\mathrm{Cd}$ and 54 times for $\mathrm{Pb}$.

Although the fishing population presented a significant difference in the metal exposure risk compared to the control, the results found in the present study indicated a low risk of metal contamination from fish intake from Sepetiba Bay in both populations investigated. The hazard index was in the range of $3 \times 10^{-4}$ to $4 \times 10^{-5}$ for the control population and $1 \times 10^{-2}$ to $2 \times 10^{-3}$ for the fishing population. T. paulistanus was the species with the highest hazard index, while $S$. vomer showed the lowest hazard index (Table 4). 
Table 3 - Maximum metal concentrations for human consumption.

\begin{tabular}{|c|c|c|c|}
\hline \multirow[t]{2}{*}{ Legislation } & \multicolumn{3}{|c|}{$\mu \mathrm{g} \mathrm{g}^{-1}$ wet weight } \\
\hline & As & $\mathrm{Cd}$ & $\mathrm{Pb}$ \\
\hline ANVISA (2013) & 1.0 & $\begin{array}{c}0.05 \\
0.1 \text { (Bonito, Carapeta, enguia, tainha, jurel, imperador, } \\
\text { cavala, sardinha, atum, linguado) } \\
0.2 \text { (Melva) } \\
0.3 \text { (Anchova, Espada) }\end{array}$ & 0.3 \\
\hline FAO (2011) & - & 2.0 & 0.3 \\
\hline $\begin{array}{l}\text { European Commission (2006, } \\
\text { 2008) }\end{array}$ & - & $\begin{array}{l}\text { 0.05 } \\
0.1 \text { (Sarda sarda, Diplodus vulgaris, Anguilla anguilla, } \\
\text { Mugil labrosus labrosus, Trachurus species, Luvarus } \\
\text { imperialis, Scomber species; Sardina pilchardus, } \\
\text { Sardinops species, Thunnus species, Euthynnus species, } \\
\text { Katsuwonus pelamis, Dicologoglossa cuneata) } \\
0.2 \text { (Auxis species) } \\
0.3 \text { (Engraulis species; Xiphias gladius) }\end{array}$ & 0.3 \\
\hline
\end{tabular}

\subsection{METALS IN SUSPENDED PARTICULATE MATTER}

In the present study, the concentrations of $\mathrm{Cd}, \mathrm{Cu}, \mathrm{Pb}$ and $\mathrm{Zn}$ in suspended particulate matter (SPM) from Sepetiba Bay were lower than those found in previous reports (LACERDA et al., 1987; FRANZ 2004) (Table 5). This reduction in metals in SPM is related to diverse initiatives that

\subsection{BIOSEDIMENT ACCUMULATION FACTOR}

The BSAF of the bioavailable fraction of metals in the sediment followed the decreasing sequence $\mathrm{Cu}>\mathrm{Pb}>\mathrm{Cd}>\mathrm{Zn}>\mathrm{Fe}$, while the decreasing sequence of the BSAF for the particulate matter was $\mathrm{Zn}>\mathrm{Cu}>\mathrm{Pb}>\mathrm{Al}$. Meanwhile, in fish muscle, the order of accumulation was $\mathrm{Zn}>\mathrm{Fe}>\mathrm{Al}>\mathrm{As}>\mathrm{Cu}>\mathrm{Cd}$.

The metal concentrations in sediments (bioavailable fraction) and SPM were higher than that in fish muscle, indicating a low transference between the environmental compartments to muscle tissue in fish. However, the As in fish muscle showed concentrations superior to that recommended for human consumption, indicating that chronic contamination was misrepresented by the sediment and SPM concentrations. For this reason, food items would have a greater influence on the concentration of metals (which varies between species) in the studied organisms.

By applying the data of the present study (Table 1) and the metal concentrations in shrimp (Litopenaeus schmitti) sampled from 2011-2012 (NASCIMENTO et al., 2016), have occurred since 2008 to clean up the bay once almost all the superficial contaminated sediment from the northern region of the bay was dredged and kept in subaquatic confined disposal facilities in the bottom of the bay.

we calculated the BSAFs. The BSAF results for the sediment bioavailable fraction were 0.04 for $\mathrm{Zn}$ and $\mathrm{Cd}, 3.1$ for $\mathrm{Cu}$ and 0.003 for $\mathrm{Pb}$. Meanwhile, the BSAFs in the particulate fraction were 0.1 for $\mathrm{Zn}, 0.7$ for $\mathrm{Cu}$ and 0.001 for $\mathrm{Pb}$. These results showed that the BSAFs for shrimp were one order of magnitude higher than those in the fish in the present study.

Wanick et al. (2013) also found BSAF values (58.2 for $\mathrm{Zn} ; 1.5$ for $\mathrm{Cd}$ and 5.7 for $\mathrm{Cu})$ that were hundreds of times higher in the digestive gland of the oyster Crassostrea rhizophorae from Sepetiba Bay when compared to the values found in fish and shrimp.

The lower BSAF values found in the present study illustrated the capacity for metal homeostasis in fish, although studies have indicated that $>50 \%$ of metal is weakly bound to sediments (RODRIGUES et al., 2017). Moreover, the target organs in the metal detoxification process in fish are the liver, gills and kidney. In the present study, muscle was analysed, which can indicate chronic exposure. 


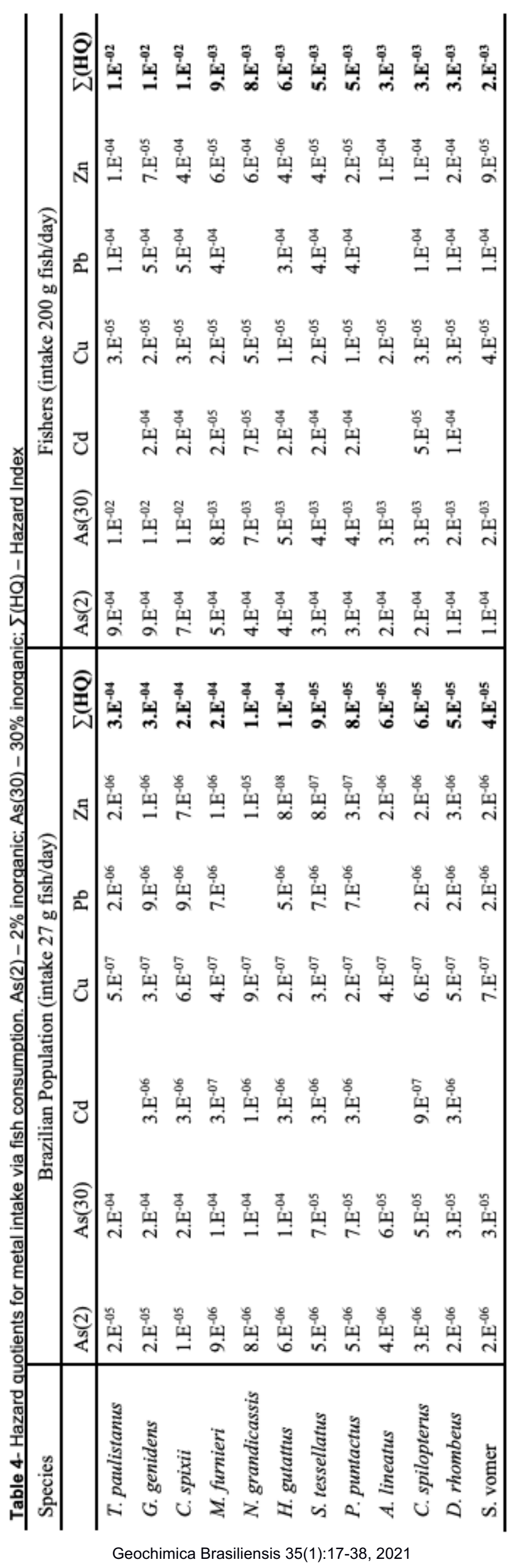


Table 5 - Historical metal $\left(\mu \mathrm{g} \mathrm{g}^{-1}\right)$ concentrations in the SPM of Sepetiba Bay.

\begin{tabular}{ccccc}
\hline Author & Cd & \multicolumn{4}{c}{ Mean (min-max) dry weight } \\
Cu & Pb & Zn \\
\hline LACERDA et al. 1987 & 3.2 & 61.6 & 139.0 & 390.0 \\
LACERDA et al. 1988 & 3.2 & 85.0 & 68.2 & 478.0 \\
FRANZ 2004 & 4.1 & - & 52.7 & 752.7 \\
FRANZ 2004 & & - & 39.7 & 749.9 \\
Present work & 3.2 & 28.4 & 51.8 & 332.4 \\
& $<0.002-1.3$ & $(<0.002-116.1)$ & $(<0.001-339.5)$ & $(<0.02-4887.4)$ \\
\hline
\end{tabular}

\section{CONCLUSIONS}

The BSAFs from the bioavailable sediment fractions and suspended particulate matter showed lower metal transference to fish muscle. Considering this result, we can hypothesize that the most important pathway for metal contamination in fish in the bay is via the food web. The concentrations of As observed in the species C. spixii, G. genidens and T. paulistanus were above those allowed for human consumption by Brazilian legislation. However, the estimated probability and risk of metal intake via fish consumption showed

\section{ACKNOWLEDGEMENTS}

This study was financed in part by the Coordenação de Aperfeiçoamento de Pessoal de Nível Superior-Brazil (CAPES)Finance Code 001. We appreciate the

\section{REFERENCES}

AMADO FILHO G.M.; ANDRADE L.R.; KAREZ C.S.; FARINA M.; PFEIFFER W.C. Brown algae species as biomonitors of $\mathrm{Zn}$ and Cd at Sepetiba Bay, Rio de Janeiro, Brazil. Marine Environmental Research, 48:213224, 1999 https://doi.org/10.1016/S01411136(99)00042-2.

AMADO FILHO G.M.; CREED J.C.; ANDRADE L.R.; PFEIFFER W.C. Metal accumulation by Halodule wrightii populations. Aquatic Botanic, 80:241-251, 2004

https://doi.org/10.1016/j.aquabot.2004.07.011

AMARAL M.C.R.; REBELO M.F.; TORRES J.P.M.; PFEIFFER W.C. Bioaccumulation and depuration of $\mathrm{Zn}$ and $\mathrm{Cd}$ in mangrove oysters (Crassostrea rhizophorae, Guilding, 1828) transplanted to and from a contaminated tropical coastal lagoon. Marine Environmental Research, 59(4): 277- 285, 2005 that the consumption of $0.2 \mathrm{Kg} \mathrm{day}^{-1}$ of all species presented low risk. Due to the high toxicity of As, future studies are necessary to investigate the chemical speciation of this element in the environmental compartments and biota of Sepetiba Bay to determine the source (whether natural or anthropogenic) of this metal. Moreover, other studies are needed to investigate the metal contents in larval and juvenile fish in different tissues to understand the transfer of metals in the ichthyofauna of Sepetiba Bay.

support of PROPESP/UFPA. Emmanoel V. Silva-Filho is senior researcher of the Research Foundation of Rio de Janeiro (FAPERJ, Brazil) and National Council for Research and Development (CNPq, Brazil).

https://doi.org/10.1016/j.marenvres.2004.05.0 04 .

ANGELI J.L.F.; TREVIZANI T.H.; RIBEIRO A.; MACHADO E.C.; FIGUEIRA R.C.L.; MARKERT B.; FRAENZLE S., WUENSCHMANN S. Arsenic and other trace elements in two catfish species from Paranaguá Estuarine Complex, Paraná, Brazil. Environmental Monitoring and Assessment, 185:8333-42, 2013 https://doi.org/10.1007/s10661-013-3176-5

ANVISA. RESOLUÇÃO - RDC No- 42, de 29de agosto de 2013. Dispõe sobre o Regulamento Técnico MERCOSUL sobre Limites Máximos de Contaminantes Inorgânicos em Alimentos. Diário Oficial da União, Brazil.

AZEVEDO J.D.S.; HORTELLANI M.A.; SARKIS J.E.D.S. Accumulation and distribution of metals in the tissues of two catfish species from Cananéia and Santos-São Vicente estuaries. Brazilian Journal of Oceanography, 60: 463-472, 2012 
http://dx.doi.org/10.1590/S1679-

87592012000400005.

BARBIERI E.; PASSOS E.D.A.; ARAGÃO K.A.S.; SANTOS D.B.; GARCIA C.A.B. Assessment of trace metal levels in catfish (Cathorops spixii) from Sal River estuary, Aracaju, state of Sergipe, northeastern Brazil. Water Environment Research, 82: 2301-2305, 2010 https://doi.org/10.2175/106143009X124654359 82935.

BARCELLOS C.; LACERDA L.D. Cadmium and zinc source assessment in the Sepetiba Bay and basin region, Environmental Monitoring and Assessment, 29, 183-199, 1994 https://doi.org/10.1007/BF00546874.

BARCELLOS C.; LACERDA L.D.; CERADINI S. Sediment origin and budget in Sepetiba Bay (Brazil) an approach based on multielemental analysis. Environmental Geology, 32:203209 ,

1997 https://doi.org/10.1007/s002540050208.

BARCELLOS C.; REZENDE C.E.; PFEIFFER W.C. $\mathrm{Zn}$ and Cd production and pollution in a Brazilian coastal region. Marine Pollution Bulletin, 22:558-561, 1997 https://doi.org/10.1016/0025-326X(91)90896Z.

BERVOETS L.; BLUST R. Metal concentrations in water, sediment and gudgeon (Gobio gobio) from a pollution gradient: Relationship with fish condition factor. Environmental Pollution, 126:9-19, 2003 https://doi.org/10.1016/S02697491(03)00173-8.

BONDY S.C. The neurotoxicity of environmental aluminium is still an issue. Neurotoxicology, 31:575-581, 2010 https://doi.org/10.1016/j.neuro.2010.05.009.

CARNEIRO C.S.; MÁRSICO E.T.; DE JESUS E.F.O.; RIBEIRO R.O.R.; BARBOSA R.F. Trace elements in fish and oysters from Sepetiba Bay (Rio de Janeiro - Brazil) determined by total reflection X-ray fluorescence using synchrotron radiation. Chemistry and Ecology, 27:1-8, 2011 https://doi.org/10.1080/02757540.2010.529249.

CARQUEIJA C.R.G.; SOUZA-FILHO J.J.; GOUVÊA E.P.; QUEIROZ E.L. Decápodos (Crustacea) utilizados na alimentação de Dasyatis guttata (Bloch \& Schneider) (Elasmobranchii, Dasyatididae) na área de influência da Estação Ecológica Ilha do Medo, Baía de Todos os Santos, Bahia, Brasil. Revista Brasileira Zoologia, 12, n.4, p.833838, 1995. http://dx.doi.org/10.1590/S010181751995000400013.

CARVALHO GOMES F.; GODOY J.M.; GODOY M.L.D.P.; DE CARVALHO Z.L.; LOPES R.T.; SANCHEZ-CABEZA J.A.; LACERDA L.D.; WASSERMAN J.C. Metal concentrations, fluxes, inventories and chronologies in sediments from Sepetiba and Ribeira Bays: a comparative study. Marine Pollution Bulletin, 59: 123-33, 2009 https://doi.org/10.1016/j.marpolbul.2009.03.0 15.

CARVALHO C.E.V.; FARIA V.V.; CAVALCANTE M.P.O.; GOMES M.P.; REZENDE C.E. Heavy Metal Distribution in Bentonic Coastal Fish from Macae Region, R.J., Brazil. Ecotoxicology and Environmental Restoration, 3(2): 64-68, 2000

CARVALHO C.E.V.; LACERDA L.D.; GOMES M.P. Heavy metal contamination of the marine biota along the Rio de Janeiro coast, SE-Brazil. Water Air and Soil Pollution 57-58:645653 ,

1991 https://doi.org/10.1007/BF00282928.

COLLIN S.P.; HART N.S. Vision and photoentrainment in fish: The effects of natural and anthropogenic perturbation. Integrative Zoology, $10(1): \quad 15-28, \quad 2015$ https://doi.org/10.1111/1749-4877.12093.

COPELAND G.; MONTEIRO T.; COUCH S.; BORTHWICK A. Water quality in Sepetiba Bay, Brazil, Marine Environmental Research, 55, 385-408, 2003 https://doi.org/10.1016/S01411136(02)00289-1.

CORRALES D.; ACUÑA A.; SALHI M.; SAONA G.; BRUGNOLI E. Copper, zinc, mercury and arsenic content in Micropogonias furnieri and Mugil platanus of the Montevideo coastal zone, Rio de la Plata. Brazilian Journal of Oceanography, 64: 57-66, 2016 http://dx.doi.org/10.1590/S167987592016105406401.

CORREA JUNIOR J.D.; ALLODI S.; AMADOFILHO C.M.; FARINA M. Zinc accumulation in phosphate granules of Ucides cordatus hepatopancreas. Brazilian Journal Medical and Biology Research, 33: 217-221, 2000http://dx.doi.org/10.1590/S0100879X2000000200009.

CRAIG P.M.; WOOD C.M.; MCCLELLAND G.B. Oxidative stress response and gene expression with acute copper exposure in zebrafish (Danio rerio). American Journal of Physiology Regulatory Integrative and Comparative Physiology, 293:R1882R1892. 2007 https://doi.org/10.1152/ajpregu.00383.2007.

DATTA S.; GHOSH D.; SAHA D. R.; BHATTACHARAYA S.; MAZUMBER S. Chronic exposure to low concentration of arsenic is immunotoxic to fish: Role of head kidney macrophages as biomarkers of arsenic toxicity to Clarias batrachus. Aquatic Toxicology, $\quad 92: 86-94, \quad 2009$ https://doi.org/10.1016/j.aquatox.2009.01.002

DE LA TORRE F.R;, FERRARI L.; SALIBIAN A. Long-term in situ toxicity bioassays of the Reconquista River (Argentina) water with Cyprinus carpio as sentinel organism. Water Air and Soil Pollution, 121:205-215, 2000 https://doi.org/10.1023/A:1005243521758. 
DIAS H.Q.; NAYAK G.N. Geochemistry and bioavailability of mudflats and mangrove sediments and their effect on bioaccumulation in selected organisms within a tropical (Zuari) estuary, Goa, India. Marine Pollution Bulletin, 105: 227-236, 2016 https://doi.org/10.1016/j.marpolbul.2016.02.026

EDMONDS J.S.; FRANCESCONI K.A. Arsenic in seafoods: Human health aspects and regulations. Marine Pollution Bulletin, 26: 665-674, 1993 https://doi.org/10.1016/0025326X(93)90549-Y.

EUROPEAN COMMISSION. COMMISSION REGULATION (EC) No 629/2008 of 2 July 2008 amending Regulation (EC) No $1881 / 2006$ setting maximum levels for certain levels contaminants in foodstuffs.

FESTA R.A.; THIELE D.J. Copper: an Essential Metal in Biology. Current Biology,_21(21): R877-R883. 2011 https://doi.org/10.1016/j.cub.2011.09.040.

FISZMAN M.; PFEIFFER W.C.; LACERDA L.D. Comparison of methods used for extraction and geochemical distribution of heavy metals in bottom sediments from Sepetiba Bay, R.J., Environmental Technology Letter, 5, 567575, 1984 https://doi.org/10.1080/09593338409384311.

FITZGERALD D.G.; LANNO R.P.; DIXON D.G. A comparison of a sentinel species evaluation using creek chub (Semotilus atromaculatus Mitchill) to a fish community evaluation for the initial identification of environmental stressors in small streams. Ecotoxicology, $8: 33-48, \quad 1999$ https://doi.org/10.1023/A:1008853413528.

FONSECA E.M.; BAPTISTA NETO J.A.; SILVA C.G.; FERNANDEZ M.A. Stormwater impact in Guanabara Bay (Rio de Janeiro): Evidences of seasonal variability in the dynamic of the sediment heavy metals, Estuarine and Coast Shelf Science, 130, 161-168, 2013 https://doi.org/10.1016/j.ecss.2013.04.022.

FRANCIONI E.; WAGENER A.D.L.W.R.; CALIXTO R.D.C.; BASTOS G.C. Evaluation of Perna perna (Linné, 1758) as a tool to monitoring trace metals contamination in estuarine and coastal waters of Rio de Janeiro, Brazil. Journal Brazilian Chemical Society, 15:103-110, 2004 http://dx.doi.org/10.1590/S010350532004000100016.

FRANZ B. (2004). Comportamento dos Metais Cd, Zn, e Pb no Material Particulado em Suspensão na Zona de Mistura do Canal de São Francisco (Baía de Sepetiba, RJ). Dissertation (Master in Geociências Geoquímica Ambiental) - Universidade Federal Fluminense, Niterói, 2004.

FREIRE M.M.; AMORIM L.M.F.; BUCH A.C.; GONÇALVES A.D.; SELLA S.M.; CASSELLA R.J.; MOREIRA J.C.; SILVA-FILHO E.V. Polycyclic aromatic hydrocarbons in bays of the
Rio de Janeiro state coast, SE - Brazil: Effects on catfishes. Environmental Research 181, 108959, 2020 https://doi.org/10.1016/j.envres.2019.108959.

GOOSSENS H.; ZWOLSMAN J.J.G. An evaluation of the behaviour of pollutants during dredging activities. Terra et Aqua, 62:20-28, 1996

GUEDES A.P.P.; ARAÚJO F.G. Trophic resource partitioning among five flatfish species (Actinopterygii, Pleuronectiformes) in a tropical bay in south-eastern Brazil. Journal Fish Biology, 72:1035-1054, 2008 https://doi.org/10.1111/j.1095-

8649.2007.01788.x.

GUEDES A.P.P.; ARAÚJO F.G.; PESSANHA A.L.M.; MILAGRE R.R. Partitioning of the feeding niche along spatial, seasonal and size dimensions by the fish community in a tropical Bay in Southeastern Brazil. Marine Ecology, 36: $38-56, \quad 2015$ https://doi.org/10.1111/maec.12115.

HARTL M.G.J. (2002). Benthic Fish as Sentinel Organisms of Estuarine Sediment Toxicity. In: Bright, M., P.C. Dworschak; M. Stachowitsch (Eds.) 2002: The Vienna School of Marine Biology: A Tribute to Jörg Ott. Facultas Universitätsverlag, Wien: 89-100. (8) (PDF) Benthic Fish as Sentinel Organisms of Estuarine Sediment Toxicity. Available from: https://www.researchgate.net/publication/23770 8374_Benthic_Fish_as_Sentinel_Organisms_of Estuarine_Sediment__oxicity [äccessed Jan 24 2020].

HÖFLING J.C; NETO F.B.R.; FILHO A.M.P.; SOARES C.P.; SILVA M.S.R. Fish alimentation of the carangidae Family of the estuarine lagoon complex in Cananéia, São Paulo, Brazil. Revista Bioikos, 12(2):7-18, 1998

HORTA M.A.P.; FERREIRA A.P.; LUZARDO A.J.R.; BRIGNOL V.; BRASIL V.I.; FARO A.R.M.C.; PINTO W.J. Risk analysis of cadmium intake by fish consumers in a subtropical coastal lagoon, Sepetiba bay-SE, Brazil, RBPS, 24(1): 46-53, jan./mar. 2011

IBGE (2010). Censo demográfico do Brasil 2010. https:/censo2010.ibge.gov.br/

JIMÉNEZ-TENORIO N.; MORALESCASELLES C.; KALMAN J.; SALAMANCA M.J.; CANALES L.G.; SARASQUETE C.; DELVALLS T.A. Determining sediment quality for regulatory proposes using fish chronic bioassays. Environment International, $33: \quad 474-480, \quad 2007$ http://dx.doi.org/10.1016/j.envint.2006.11.00 9.

JONES R.E.; PETRELL R.J.; PAULY, D. Using modified length-weight relationship to assess the condition of fish. Aquacultural Engineering. 20(4): 261-276, 1999 https://doi.org/10.1016/S01448609(99)00020-5. 
KAREZ C.S.; MAGALHÃES V.F.; PFEIFFER W.C.; AMADO FILHO G.M. Trace metal accumulation by algae in Sepetiba Bay, Brazil. Environmental Pollution, 83:351-356, 1994 https://doi.org/10.1016/0269-7491(94)901570 .

KEHRIG H.A.; COSTA M.; MALM O. Estudo da contaminação por metais pesados em peixes e mexilhão da Baía de Guanabara - Rio de Janeiro. Tropical Oceanography, 35:32-50, 2007 https://doi.org/10.5914/tropocean.v35i12.5081.

KIM B.S.M.; SALAROLI A.B.; FERREIRA P.A L.; SARTORETTO J.R.; MAHIQUES M.M.; FIGUEIRA R.C.L. Spatial distribution and enrichment assessment of heavy metals in surface sediments from Baixada Santista, Southeastern Brazil, Marine Pollution Bulletin, $103 \quad(1-2), \quad 333-338, \quad 2016$ https://doi.org/10.1016/j.marpolbul.2015.12.041

KIRBY J.; MAHER W. Tissue accumulation and distribution of arsenic compounds in three marine fish species: Relationship to trophic position. Applied Organometallic Chemistry, $\quad 16: 108-115, \quad 2002$ https://doi.org/10.1002/aoc.268.

LACERDA L.D.; PFEIFFER W.C.; FISZMAN M. Heavy metal distribution, availability and fate in Sepetiba bay, S.E. Brazil. Science of the Total Environment, 65:163-173, 1987 https://doi.org/10.1016/0048-9697(87)901690 .

LACERDA L.D.; MARTINELLI L.A.; REZENDE, C.E.; MOZETO A.A.; OVALLE A.R.C.; VICTORIA R.L.; SILVA C.A.R.; NOGUEIRA F.B. The fate of trace metals in suspended matter in a mangrove creek during a tidal cycle, The Science of Total Environment, $\quad 75 \quad$ (2-3). 1988 https://doi.org/10.1016/0048-9697(88)90030-7.

LAFABRIE C.; PERGENT G.; KANTIN R.; PERGENT-MARTINI C.; GONZALEZ J.L. Trace metals assessment in water, sediment, mussel and seagrass species--validation of the use of Posidonia oceanica as a metal biomonitor. Chemosphere, 68:2033-9, 2007 https://doi.org/10.1016/j.chemosphere.2007.02. 039.

LIMA N.; LACERDA L.D.; PFEIFFER W.C.; FISZMAN M. Temporal and spatial variability in $\mathrm{Zn}, \mathrm{Cr}, \mathrm{Cd}$ and $\mathrm{Fe}$ concentrations in oyster tissues (Crassostrea brasiliana lamarck, 1819) from sepetiba bay, Brazil. Environmental Technology Letter, 1986, 7:453-460, 1986 https://doi.org/10.1080/09593338609384432.

MAGALHÃES V.F.; CARVALHO C.E.V.; PFEIFFER W.C. Arsenic contamination and dispersion in the Engenho Inlet, Sepetiba Bay, SE, Brazil. Water Air and Soil Pollution, 129:83-90, 2001 https://doi.org/10.1023/A:1010381902874.

MEDEIROS R.J.; DOS SANTOS L.M.G.; FREIRE A.S.; SANTELLI R.E.; BRAGA
A.M.C.B.; KRAUSS T.M.; JACOB S.C. Determination of inorganic trace elements in edible marine fish from Rio de Janeiro State, Brazil. Food Control, 23:535-541, 2012 https://doi.org/10.1016/j.foodcont.2011.08.02 7.

MENDES, F. L. S.; BARTHEM, R. B. Hábitos alimentares de bagres marinhos (siluriformes: Ariidae) do estuário amazônico. Amazônia: Ciências \& Desenvolvimento, 5(10):153, 2010

MIRLEAN N.; BAISCH P.; TRAVASSOS M.P.; NASSAR C. Calcareous algae bioclast contribution to sediment enrichment by arsenic on the Brazilian subtropical coast. GeoMarine Letters, 31:65-73, 2011 https://doi.org/10.1007/s00367-010-0215-X.

MIRLEAN N.; CALLIARI L.; BAISCH P.; SHUMILIN E. Urban activity and mercury contamination in estuarine and marine sediments (Southern Brazil), Environmental Monitoring and Assessment, 157, 583-589, 2009 https://doi.org/10.1007/s10661-008-0558-1.

MIRLEAN N.; MEDEANIC S.; GARCIA F.A.; TRAVASSOS M.P.; BAISCH P. Arsenic enrichment in shelf and coastal sediment of the Brazilian subtropics. Continental Shelf Research, 35:129-136,2009 https://doi.org/10.1016/j.csr.2012.01.006.

MOLISANI M.M.; KJERFVE B.; SILVA A.P.; LACERDA L.D. Water discharge and sediment load to Sepetiba Bay from an anthropogenically-altered drainage basin, SE Brazil. Journal of Hydrology, 331:425-433, 2006 https://doi.org/10.1016/j.jhydrol.2006.05.038.

MONTE C.N.; RODRIGUES A.P.C.; CORDEIRO R.C.; FREIRE A.; SANTELLI R.E.; MACHADO W. Changes in $\mathrm{Cd}$ and $\mathrm{Zn}$ bioavailability upon an experimental resuspension of highly contaminated coastal sediments from a tropical estuary. Sustainable Water Resources Management, 1:335-342, 2015 https://doi.org/10.1007/s40899-0150034-3.

MUÑOZ L.; WEBER P.; DRESSLER V.; BALDISSEROTTO B.; VIGLIANO F.A. Histopathological biomarkers in juvenile silver catfish (Rhamdia quelen) exposed to a sublethal lead concentration. Ecotoxicology and Environmental Safety, 113: 241-247, 2015 https://doi.org/10.1016/j.ecoenv.2014.11.036.

MURRAY J.; BURT J.R. The Composition of Fish. Ministry of Technology. Torry Research Station. Torry Advisory Note No. 38 Storbritannien. Ministry of Agriculture, Fisheries and Food. Editora Torry Research Station. 1983

NASCIMENTO J.R.; BIDONE E.D.; ROLÃOARARIPE D.; KEUNECKE K.A.; SABADINI-SANTOS E. Trace metal distribution in white shrimp (Litopenaeus schmitti) tissues from a Brazilian coastal area. 
Environmental Earth Science, 75: 990, 2016 https://doi.org/10.1007/s12665-016-5798-8.

NENDZA $M$. Inventory of marine biotest methods for the evaluation of dredged material and sediments. Chemosphere, 48(8): 865883,2002 https://doi.org/10.1016/S00456535(02)00003-6.

NIENCHESKI L.F.; MACHADO E.C.; SILVEIRA I.M.O.; MONTES M.J.F. Metais traço em peixes e filtradores em quatro estuários da costa brasileira. Tropical Oceanography, 42:94-106, 2014 https://doi.org/10.5914/tropocean.v42i1.5886.

PHILLIPS D.J.H. The use of biological indicator organisms to monitor trace metal pollution in marine and estuarine environments - a review. Environmental Pollution, 13:281-317, 1977 https://doi.org/10.1016/0013-9327(77)900477.

PLAYLE, R.C.; GOSS, G.G.; WOOD, C.M. Physiological disturbances in brown trout (Salmo gairdneri) during acid and aluminium exposures in soft water of two calcium concentrations. Canadian Journal of Zoology, 67:314-324, 1989 https://doi.org/10.1139/z89-046.

RANNEY S.H.; FINCEL M.J.; WUELLNER M.R.; VANDEHEY J.A.; BROWN M.L. Assessing length-related bias and the need for data standardization in the development of standard weight equations. North American Journal of Fisheries Management 30(3):655-666, 2010 https://doi.org/10.1577/M08-097.1.

REBELO M.F.; AMARAL M.C.R.; PFEIFFER W.C. High $\mathrm{Zn}$ and $\mathrm{Cd}$ accumulation in the oyster Crassostrea rhizophorae and its relevance as a sentinel species. Marine Pollution Bulletin, 46:1341-1358, 2003 https://doi.org/10.1016/S0025326X(03)00244-3.

REBELO, M. F.; PFEIFFER, W. C.; SILVA, H.; MORAES, M. O. Cloning and detection of metallothionein mRNA by RT-PCR in mangrove oysters (Crassostrea rhizophorae). Aquatic Toxicology, 64:359-362, 2003 doi: 10.1016/S0166-445X(03)00059-6

RENBERG I.; BRÄNNVALL M-L.; BINDLER R.; EMTERYD O. Atmospheric lead pollution history during four millennia $(2000 \mathrm{BC}$ to 2000 AD) in Sweden. AMBIO. A Journal of the Human Environment, 29(3): 150-156, 2000 https://doi.org/10.1579/0044-744729.3.150.

RIBEIRO A.P.; FIGUEIREDO A.M.G.; DOS SANTOS J.O.; DANTAS E.; COTRIM M.E.B.; FIGUEIRA R.C.L.; SILVA FILHO E.V.; WASSERMAN J.C. Combined SEM/AVS and attenuation of concentration models for the assessment of bioavailability and mobility of metals in sediments of Sepetiba Bay (SE Brazil). Marine Pollution Bulletin, 68: 55-63, 2013 https://doi.org/10.1016/j.marpolbul.2012.12.0 23.
RODRIGUES R.P.; KNOPPERS B.A.; LANDIM DE SOUZA W.F.; SANTOS E.S. Suspended Matter and Nutrient Gradients of a SmallScale River Plume in Sepetiba Bay, SE-Brazil. Brazilian Archives of Biology and Technology, 52(2): 503-512, 2009

RODRIGUES S.K.; ABESSA D.M.S.; RODRIGUES A.P.C.; SOARES-GOMES A.; FREITAS C.B.; SANTELLI R.E.; FREITAS A.S.; MACHADO W. Sediment quality in a metal-contaminated tropical bay assessed with a multiple lines of evidence approach. Environmental Pollution, 228:265-276, 2017 http://dx.doi.org/10.1016/j.envpol.2017.05.04 5.

SHAFER M.; OVERDIER J. Analysis of Surface Waters for Trace Elements by Inductively Coupled Plasma Mass Spectrometry. Water Chemistry Program University of WisconsinMadison Madison, WI 53706, Revision 4. 1995

SHIAU S.Y.; SU L.W. Ferric citrate is half as effective as ferrous sulfate in meeting the iron requirement of juvenile tilapia, Oreochromis niloticus $\times O$. aureus. Journal of Nutrition, 133: 483-488, 2003 https://doi.org/10.1093/jn/133.2.483.

SILBERGELD E.K.; WAALKES M.; RICE J.M. Lead as a carcinogen: Experimental evidence and Mechanisms of Action. American Journal of Industrial Medicine, 38:316-323, $2000 \quad$ https://doi.org/10.1002/10970274(200009)38:3<316::AIDAJIM11>3.0.CO;2-P.

SILVA G.B.; VIANA M.S.R.; FURTADONETO M.A.A. Morfologia e alimentação de raia Dasyatis guttata (Chondrichthyes: Dasyatidae) na enseada do Mucuripe, Fortaleza, Ceará. Arquivos de Ciências do Mar, 34, 2001 http://dx.doi.org/10.32360/acmar.v34i12.11715 .

TONHÁ M.S.; GARNIER J.; ARAÚJO D.F.; CUNHA B.C.A.; MACHADO W.; DANTAS E.; ARAÚJO R.; KÜTTER V.T.; BONNET M-P.; SEYLER P. Behavior of metallurgical zinc contamination in coastal environments: A survey of $\mathrm{Zn}$ from electroplating wastes and partitioning in sediments. Science of the Total Environment 743, 140610. 2020 https://doi.org/10.1016/j.scitotenv.2020.1406 10

U.S EPA, Integrated Risk Information System (IRIS) Chemical Assessment Summary Arsenic, inorganic; CASRN 7440-38-2. Washington, 1991, Environmental Protection Agency, DC: U.S.

U.S. EPA, A Review of the Reference Dose and Reference Concentration Processes. U.S. Environmental Protection Agency, Risk Assessment Forum, Washington, DC, 2002, EPA/630/P-02/002F.

USERO J.; MORILLO J.; GRACIA I. Heavy metal concentrations in molluscs from the Atlantic coast of southern Spain. Chemosphere, 59 
(8):1175-1181, https://doi.org/10.1016/j.chemosphere.2004.11. 089.

UTHUS E.O. Evidence for arsenic essentiality. Environmental Geochemistry and Health, 14:55-58, 1992 https://doi.org/10.1007/BF01783629.

VAN DER OOST R.; BEYER J.; VERMEULEN N.P.E. Fish bioaccumulation and biomarkers in environmental risk assessment: a review. Environmental Toxicology and Pharmacology, 13:57-149, 2003 https://doi.org/10.1016/S13826689(02)00126-6.

VILLA-LOJO M.C.; ALONSO-RODRÍGUEZ E.; LÓPEZ-MAHÍA P.; MINIATEGUILORENZO S.; PRADA-RODRIGUEZ D. Coupled high performance liquid chromatography-microwave digestionhydride generation-atomic absorption spectrometry for inorganic and organic arsenic speciation in fish tissue. Talanta, 57:741-750, 2002 https://doi.org/10.1016/S00399140(02)00094-2.

WANICK R.C.; KÜTTER V.T.; TEIXEIRA C.L.; CORDEIRO R.C.; SANTELLI R.E. Use of the digestive gland of the oyster Crassostrea rhizophorae (Guilding, 1828) as a bioindicator of
$\mathrm{Zn}, \mathrm{Cd}$ and $\mathrm{Cu}$ contamination in estuarine sediments (south-east Brazil). Chemistry and. Ecology, 28:103-111, 2012 https://doi.org/10.1080/02757540.2011.638630.

WILLIAMS J.E. The coefficient of condition of fish. In: Schneider, J.C. (Ed.), The manual of fisheries survey methods II: with periodic updates. Michigan Department of Natural Resources, Fisheries special report 25, Ann Arbor, Michigan. 2000

WITTERS H.E.; VAN PUYMBROECK S.; VANDERBORGHT O.L.J. Adrenergic response to physiological disturbances in rainbow trout, Oncorhynchus mykiss, exposed to aluminium at acid $\mathrm{pH}$. Canadian Journal of Fisheries and Aquatic Sciences, 48:414-420, 1991 https://doi.org/10.1139/f91-053.

WOOD C.M.; FARRELL A.P.; BRAUNER C.J. Homeostasis and toxicology of essential metals. Elsevier, London. 2012a

WOOD C.M.; FARRELL A.P.; BRAUNER C.J. Homeostasis and toxicology of non-essential metals. Elsevier, London. 2012b

YOUNESS E.R.; MOHAMMED N.A.; MORSY F.A. Cadmium impact and osteoporosis: mechanism of action. Toxicology Mechanisms and Methods, 22(7):560-567, 2012 https://doi.org/10.3109/15376516.2012.702796. 


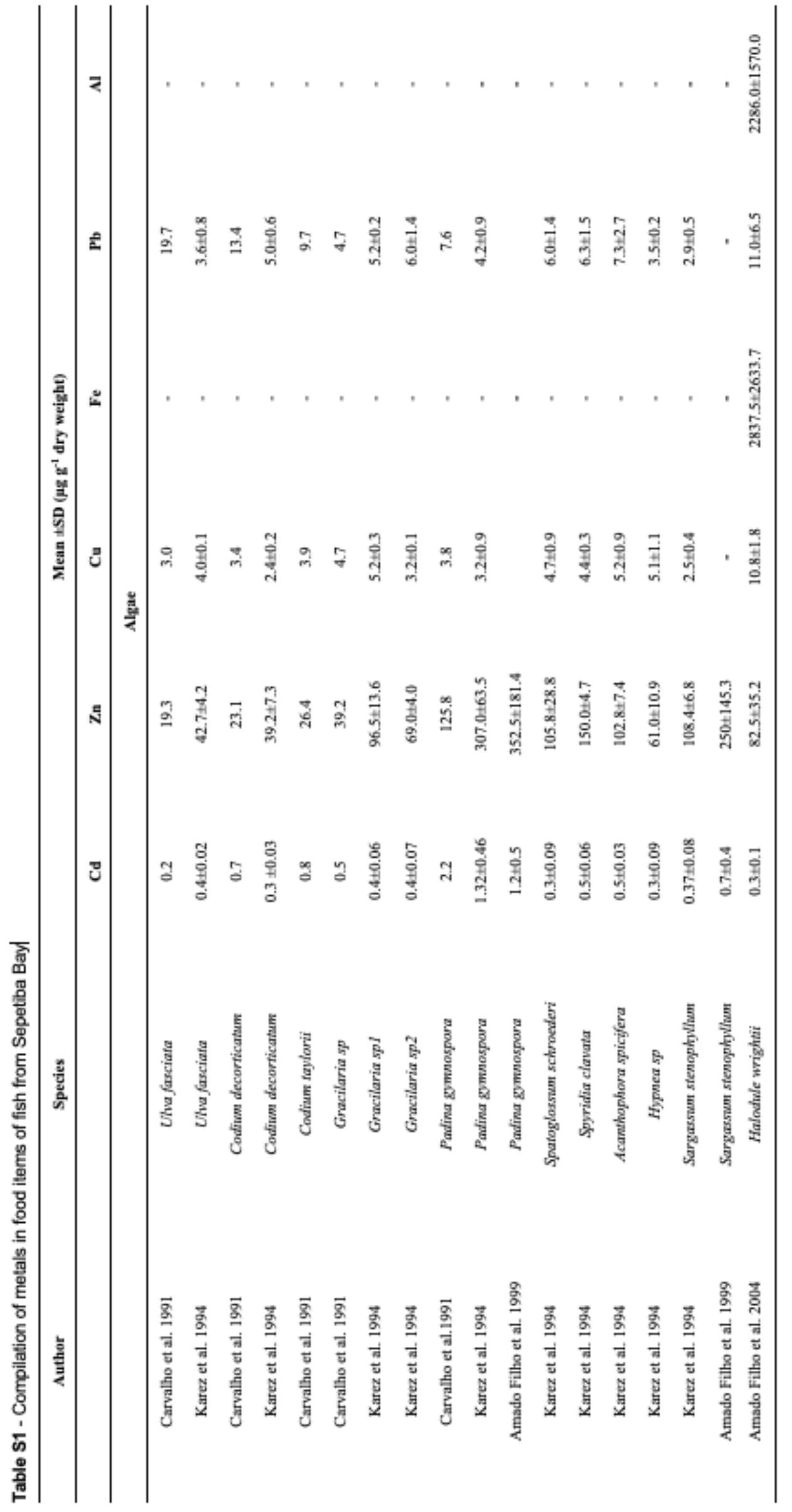




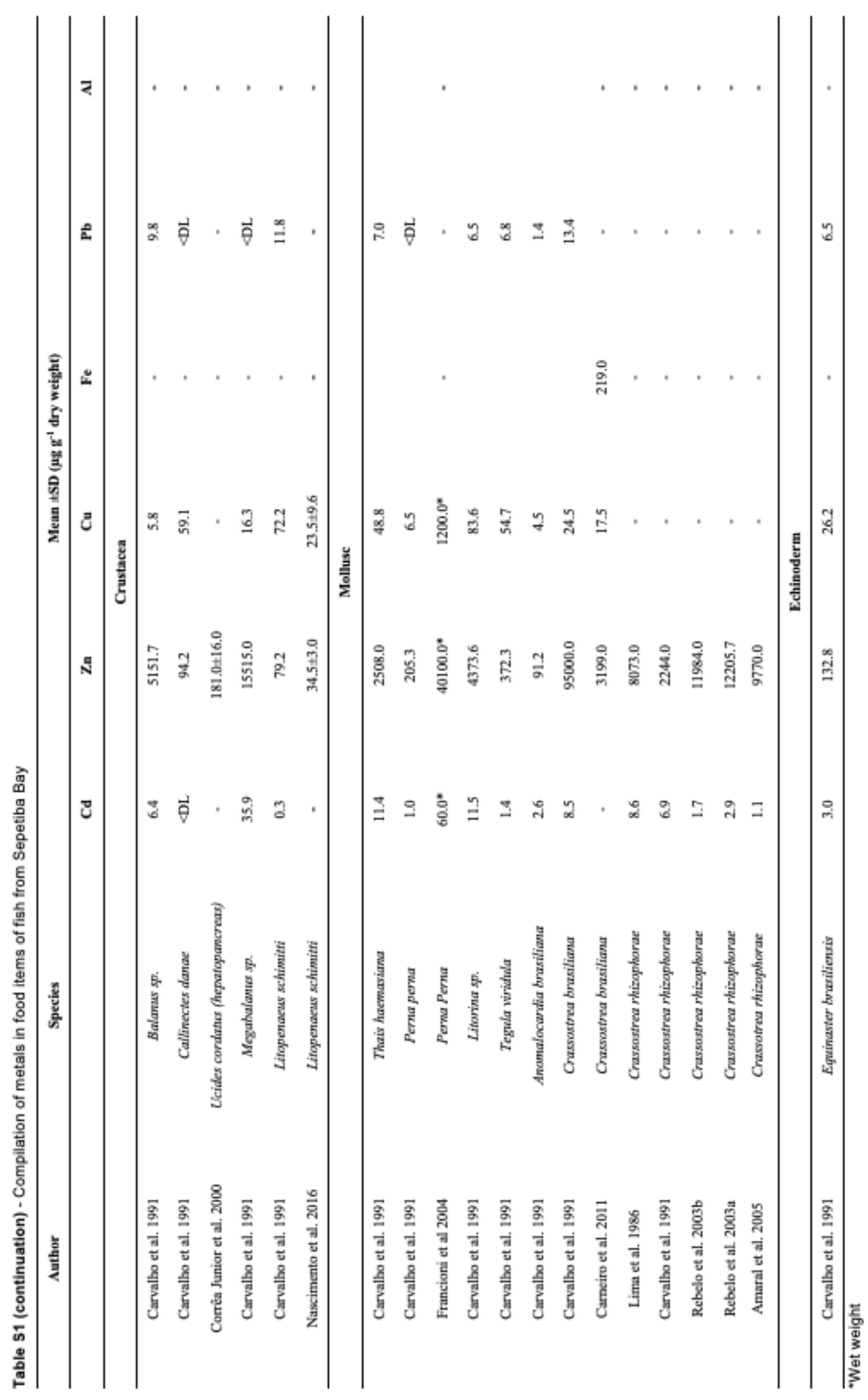




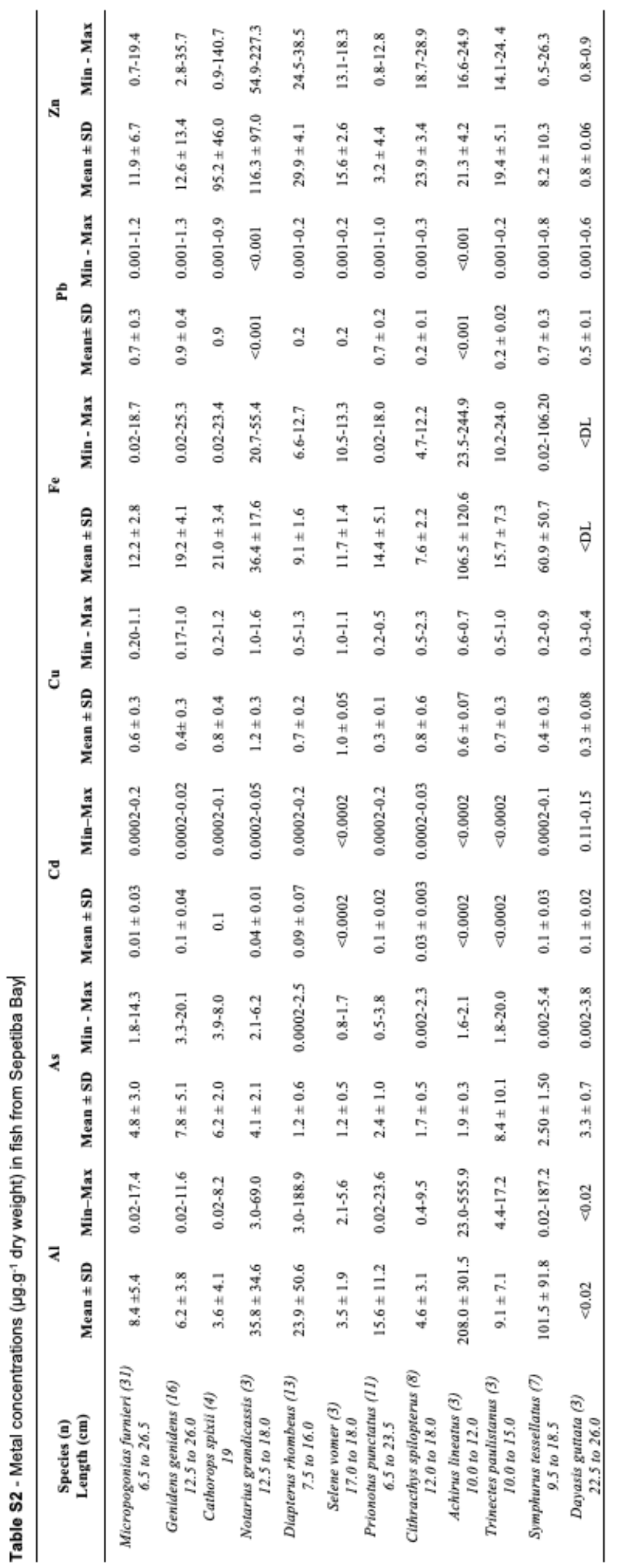

